\title{
Do Parties to Nuisance Cases Bargain After Judgment? A Glimpse Inside the Cathedral
}

\author{
Ward Farnsworth $\dagger$
}

\begin{abstract}
Economic analysts of remedies often use nuisance cases as examples to illustrate their models. The illustrations commonly suppose that parties to such cases will be interested in bargaining after judgment if the court fails to award the rights to the party willing to pay the most for them. Professor Farnsworth examines twenty nuisance cases and finds no bargaining after judgment in any of them; nor did the parties' lawyers believe that bargaining would have occurred if judgment had been given to the loser. The lawyers said that the possibility of such bargaining was foreclosed not by the sorts of transaction costs that usually are the subject of economic models, but by animosity between the parties and by their distaste for cash bargaining over the rights at issue. Professor Farnsworth suggests that these results raise a number of interesting questions, such as how the obstacles to bargaining in these cases might be related to the absence of markets for the rights at stake, whether animosity or a distaste for bargaining should be considered transaction costs, and whether greater particularity might be needed before economic models can generate advice about remedies reliable enough to be useful to courts.
\end{abstract}

\section{INTRODUCTION}

For about as long as there has been economic analysis of law, there has been speculation about nuisance cases and the possibility that parties to them might bargain after judgment. Ronald Coase used nuisance cases to illustrate his argument in The Problem of Social Cost, ${ }^{1}$ and Calabresi and Melamed's famous article on property rights and liability rules likewise used nuisance cases to illustrate the nature of those remedies and when each of them might be appropriate. ${ }^{2}$ Those articles in turn have spawned a vast literature comparing the consequences of using property rights and liability rules to protect entitlements. This literature builds on the insight that parties to lawsuits can, at least in principle, continue bargaining after judgment is rendered. If bargaining is not too costly, the rights at stake in a case inevitably will end up in the hands of the party willing to pay the most for them. The literature explores how the law might facilitate such bargaining

$\dagger$ Associate Professor, Boston University School of Law. This Article has benefited from conversations with innumerable colleagues at various law schools over the past two years. Many thanks in particular to Jack Beermann, Brian Brooks, Ronald Cass, Janet Farnsworth, Claire Hill, Dan Kahan, Vikramaditya Khanna, Adam Long, Steve Marks, Richard Posner, and Cass Sunstein for helpful comments and advice.

1 Ronald H. Coase, The Problem of Social Cost, $3 \mathrm{~J} \mathrm{~L} \mathrm{\&} \mathrm{Econ} \mathrm{1,} 19-28$ (1960).

2 Guido Calabresi and A. Douglas Melamed, Property Rules, Liability Rules, and Inalienability: One View of the Cathedral, 85 Harv L Rev 1089, 1115-24 (1972). 
or, where transaction costs are prohibitive, mimic the results of a bargaining process. While most of the articles in this genre make arguments that apply to various areas of law, almost all use nuisance cases as illustrations of their approaches-and often as the main illustration. ${ }^{3}$

There rarely is any suggestion, however, that the theories and models advanced in the literature are based on observations of bargaining. The models usually are based entirely on assumptions about how people act when they are awarded or denied entitlements. While there have been occasional attempts to test the Coase theorem in controlled experiments of various kinds, ${ }^{4}$ no studies have examined what actual litigants do after judgment. This Article investigates what actually happens after courts enter judgment in nuisance cases. Do the parties keep bargaining? If so, to what final result? If not, why not? Would their behavior after judgment have been different if the court had allocated the rights differently?

Answers to these questions will not tell us how parties behave in the many cases that settle before reaching final judgment. Nor will they necessarily tell us how parties behave after judgment in other kinds of litigation. But the answers may have some practical value just the same. When scholars discuss nuisance cases, they frequently offer observations and conclusions that may have their most forceful bite elsewhere in the law. Nuisances are a "stock example" intended to illuminate bigger issues. So while this Article focuses on a particular type of legal problem, it may have implications for the economic analysis of other areas of law as well.

I will begin in Section I by describing in more detail the reasons for the inquiry undertaken in this Article. Section II will de-

3 For some recent examples, see Ian Ayres and Eric Talley, Solomonic Bargaining: Dividing a Legal Entitlement To Facilitate Coasean Trade, 104 Yale L J 1027, 1064, 10991100 (1995); Keith N. Hylton, A Missing Markets Theory of Tort Law, 90 Nw U L Rev 977, 993-1006 (1996); Louis Kaplow and Steven Shavell, Property Rules Versus Liability Rules: An Economic Analysis, 109 Harv L Rev 713, 754-55 (1996); James E. Krier and Stewart J. Schwab, Property Rules and Liability Rules: The Cathedral in Another Light, 70 NYU L Rev 440, 444-45, 466-75 (1995); Saul Levmore, Unifying Remedies: Property Rules, Liability Rules, and Startling Rules, 106 Yale L J 2149, 2166-67 (1997).

- See, for example, Don L. Coursey, Elizabeth Hoffman, and Matthew L. Spitzer, Fear and Loathing in the Coase Theorem: Experimental Tests Involving Physical Discomfort, 16 $J$ Legal Stud 217 (1987); Elizabeth Hoffman and Matthew L. Spitzer, Experimental Tests of the Coase Theorem with Large Bargaining Groups, $15 \mathrm{~J}$ Legal Stud 149 (1986). For an interesting real-world empirical inquiry into the Coase theorem's operation in the employment context, see John J. Donohue III, Diverting the Coasean River: Incentive Schemes to Reduce Unemployment Spells, 99 Yale L J 549 (1989). See also Robert Ellickson, Order without Law: How Neighbors Settle Disputes (Harvard 1991).

${ }^{5}$ Krier and Schwab, 70 NYU L Rev at 442 (cited in note 3). 
scribe the research methodology; Section III will recount the results. I will explore how the results might be interpreted in Section IV and consider some limitations on the reach of the study in Section V.

\section{THE QUESTION}

Economic analysts have developed various models to describe the consequences of using property rights and liability rules as remedies. While there are many variations on these models, they all tend to involve certain common premises. One is that if a court fails to award the rights in a case to the party willing to pay the most for them, that party will be interested in buying the rights from the winner so long as bargaining is feasible (or, to be precise, so long as the gains from trade exceed the costs of arranging a trade). Another common assumption is that nuisance cases involving few parties often provide good examples of this dynamic. This Section reviews the development of these two assumptions in the literature of law and economics and explains why they are promising subjects for empirical examination.

The core insight underlying the economic analysis of property rights and liability rules as remedies runs as follows, in its simplest and least controversial form: if (a) a court is considering awarding a property right to one of the two parties to a dispute, and (b) it is clear that if the court does this, the parties will want to make a deal in which the winner would sell the rights to the loser, but (c) the parties would have trouble effecting this wish because of logistical problems ("transaction costs"), then (d) the court has a good reason to replace the property right with an award of damages that is equivalent to the deal that the parties would make after judgment if they could. The difficulty with this analysis is that courts often have to make decisions without being sure about (b) or (c). Most of the literature on property rights and liability rules amounts to advice to courts about how to act in the face of that uncertainty: theories about when to expect that parties will bargain after judgment or will want to do so, and about how to devise remedies that will make the need for bargaining or the logistical impediments to it less serious. I have described the problem as involving a choice between remedies, but it also may be thought to have significance in deciding who wins the case. In the view of some economic theorists most concerned about efficiency as a criterion for distributing rights, entitlements ought to be assigned in the first place to the parties that would pay the most for them - the better to obviate the need for a transaction in which the loser buys the rights from the winner. But here again, 
a court may be uncertain which party would pay more for the rights, and in that case the remedial question again comes to the fore: the court's goal, perhaps, should be to devise remedies that will make bargaining after judgment as cheap as possible.

Nuisance cases are a natural source of illustrations of these theories, because they present simple and sometimes charming fact patterns in which courts must pick between awarding property rights to parties and awarding them money. A nuisance suit arises when a plaintiff complains to a court that his neighbor is interfering unreasonably with the use and enjoyment of his property-usually because the neighbor is engaging in some activity that is noisy, noisome, or otherwise offensive to the plaintiff. A typical example of a nuisance case that has figured prominently in law and economics scholarship is the old English case of Bryant $v$ Lefever. ${ }^{6}$ The plaintiff and the defendants were neighbors. The defendants began rebuilding their house. The new structure had higher walls than the old one, and the defendants also stacked timber on their roof; the wall and the timber ran alongside the plaintiff's chimney and caused some of the smoke from it to back up into the plaintiff's house. The plaintiff sued, claiming the wall was a nuisance. The court rejected the claim. Coase used this case to illustrate his analysis in The Problem of Social Cost:

The smoke nuisance was caused both by the man who built the wall and by the man who lit the fires .... On the marginal principle it is clear that both were responsible and both should be forced to include the loss of amenity due to the smoke as a cost in deciding whether to continue the activity which gives rise to the smoke. And given the possibility of market transactions, this is what would in fact happen. Although the wall-builder was not liable legally for the nuisance, as the man with the smoking chimneys would presumably be willing to pay a sum equal to the monetary worth to him of eliminating the smoke, this sum would therefore become for the wall-builder, a cost of continuing to have the high wall with the timber stacked on the roof.?

Richard Posner later clarified Coase's prediction about bargaining:

According to Coase, it does not matter whether the court [in Bryant $v$ Lefever] analyzed the case correctly or not. Since

64 CPD 172 (1878-79).

7 Coase, 3 J L \& Econ at 13 (cited in note 1). 
transaction costs were presumably low (why?), $\left.{ }^{8}\right]$ the parties would undo, by a voluntary negotiation, whatever allocative error the court committed. If the cost of the smoke to the plaintiff was greater than the cost to the defendants of avoiding interference with plaintiff's chimneys by, say, removing the timber from their roof, plaintiff would be willing to pay defendants a sum great enough to induce them to remove the timber, and the efficient result would be obtained. This is a straightforward application of the Coase theorem. ${ }^{9}$

Writers subsequent to Coase have followed suit in using nuisance cases as paradigmatic examples of the role that bargaining after judgment might play in the law. Calabresi and Melamed, for example, observe that "[n]uisance or pollution is one of the most interesting areas where the question of who will be given an entitlement, and how it will be protected, is in frequent issue"; ${ }^{10}$ the authors illustrate the argument in their paper by describing a nuisance dispute between two neighbors, Taney and Marshall. Taney creates pollution offensive to Marshall. The authors' general suggestion is that a property right-an injunction against Taney's pollution, or a finding of no liability for Taney-is a sensible remedy from an efficiency standpoint if the court thinks that the loser is the one who most cheaply can eliminate the problem. But of course a court might be wrong in making such an assessment, and the possibility of such mistakes makes it important to consider the likelihood that the parties can bargain after judgment:

If we were wrong in our judgments and if transactions between Marshall and Taney were costless or even very cheap, the [property right for one side or the other] would be traded and an economically efficient result would occur in either case. If we entitled Taney to pollute and Marshall valued clean air more than Taney valued the pollution, Marshall would pay Taney to stop polluting even though no nuisance was found. If we entitled Marshall to enjoin the pollution and the right to pollute was worth more to Taney than freedom from pollution was to Marshall, Taney would pay Marshall not to seek an injunction or would buy Marshall's land and sell it to someone who would agree not to seek an injunc-

\footnotetext{
${ }^{B}$ "Only two parties." Richard A. Posner, Teacher's Manual for Tort Law: Cases and Economic Analysis (Little, Brown 1982) (answering $n 2$ on p 738 of the casebook).

9 Richard A. Posner, Tort Law: Cases and Economic Analysis 738 (Little, Brown 1982).

${ }^{10}$ Calabresi and Melamed, 85 Harv L Rev at 1115 (cited in note 2).
} 
tion. ... Wherever transactions between Taney and Î́arshall are easy, and wherever economic efficiency is our goal, we could employ entitlements protected by property rules even though we would not be sure that the entitlement chosen was the right one. Transactions as described above would cure the error. ${ }^{11}$

The authors go on to discuss the benefits of using damages, payable by either side to the other, in cases where transaction costs are high enough to make bargaining infeasible-for example, a case where "we enjoin Taney and there are 10,000 injured Marshalls," and hold-out problems would make it impractical for all the Marshalls to enter into a deal to let Taney off the hook, much as they might like to do so. The lesson most commonly extracted from Calabresi and Melamed's analysis is that if transaction costs are low, property rights best protect whatever entitlements a court awards; if transaction costs are high, damages are better-damages calculated to replicate the exchange the parties would make if they could. ${ }^{12}$

Writers following Calabresi and Melamed often have focused on impediments to bargaining - "transaction costs"-and how remedies might be fashioned to minimize or compensate for them. The impediments discussed generally are various kinds of strategic behavior: ways the self-interested conduct of rational profitmaximizers might confound cooperation. The most commonly discussed varieties are, first, the problems involved in coordinating a negotiation that involves large numbers of people, some of whom may try to hold out for a disproportionate share of the gains from trade or freeload on the deal made by others without paying their share; and, second, the difficulties that can occur when just two parties must deal with each other (a bilateral monopoly), as the situation may tempt each side to waste time and money trying to extract a large share of the gains from trade (a problem exacerbated by each side's possession of private information about how much it really values the rights). ${ }^{13}$ Other writers have suggested

\footnotetext{
${ }^{11}$ Id at 1118.

${ }^{12}$ See Robert Cooter and Thomas Ulen, Law and Economics 106-07 (Scott, Foresman 1988); William M. Landes and Richard A. Posner, The Economic Structure of Tort Law 3031 (Harvard 1987); Richard A. Posner, Economic Analysis of Law 16, 77, 272 (Aspen 5th ed 1998). See also Krier and Schwab, 70 NYU L Rev at 451, 452-53, 453 n 44 (cited in note 3) (identifying these two propositions as "conventional wisdom" and citing authors treating them as the upshot of Calabresi and Melamed's analysis).

${ }^{13}$ For discussions of these and other transaction costs and their suggested applications to nuisance cases, see Cooter and Ulen, Law and Economics at 170-80 (cited in note 12); A. Mitchell Polinsky, Introduction to Law and Economics 18-20 (Little, Brown 2d ed 1989); Posner, Economic Analysis of Law at 68-71, 79-81 (cited in note 12).
} 
more complex possibilities as well. For instance, some have suggested that if transaction costs are low enough for the parties to bargain, they can bargain around an inefficient award of damages as well as around an inefficient injunction. ${ }^{14}$ Others argue that perhaps damages should be preferred generally because, among other reasons, they facilitate bargaining by forcing parties to reveal private information. ${ }^{15}$ Then again, courts trying to compute awards of damages might have trouble figuring out how much each side values the rights at stake in the case, and errors in making those assessments may be more costly than errors in assigning a property right to the wrong side; some writers have suggested that property rights therefore are better remedies than damages in general, even where transaction costs are high. ${ }^{16}$ And of course all this is the greatly oversimplified story. Each of these proposals has been spun out in much detail, and has been backed up with substantial economic arguments. The proposals are meant to have broad implications for the enterprise of creating remedies. But for illustrative purposes, they invariably are applied by their authors to nuisance disputes.

As noted earlier, for the most part this literature has been based on speculation about how parties might be expected to behave after judgment. The literature never discusses actual cases and what happened when they were over. But there have been occasional attempts at empiricism of other kinds. Professors Hoffman and Spitzer, for example, have run controlled studies of what university students do in situations intended to create a favorable climate for bargaining after entitlements are assigned to them. ${ }^{17}$ The general approach in these types of studies is to instruct the subjects to choose between receiving a small sum of money distributed to them in equal shares or receiving a larger sum unevenly distributed among them; the question is whether they will agree to pick the bigger amount and then redistribute it among themselves. The authors find that the subjects in these experiments tend to cooperate, and on the basis of their studies they conclude that

\footnotetext{
${ }^{14}$ See Kaplow and Shavell, 109 Harv L Rev at 732-34 (cited in note 3); A. Mitchell Polinsky, Resolving Nuisance Disputes: The Simple Economics of Injunctive and Damage Remedies, 32 Stan L Rev 1075, 1088-92 (1980).

${ }^{25}$ See generally Ayres and Talley, 104 Yale L J at 1032 (cited in note 3); Louis Kaplow and Steven Shavell, Do Liability Rules Facilitate Bargaining? A Reply to Ayres and Talley, 105 Yale L J 221 (1995); Ian Ayres and Eric Talley, Distinguishing Between Consensual and Nonconsensual Advantages of Liability Rules, 105 Yale L J 235 (1995).

${ }^{16} \mathrm{Krier}$ and Schwab, 70 NYU L Rev at 464 (cited in note 3). See also Saul Levmore, Explaining Restitution, 71 Va L Rev 65, 79-81 (1985).

${ }^{17}$ Hoffman and Spitzer, $15 \mathrm{~J}$ Legal Stud at 151 (cited in note 4).
} 
these results produce a presumption in favor of the Coase Theorem for disputes involving substantial numbers of parties. By "a presumption in favor of the Coase Theorem" we mean that a judge or legislator who is considering choosing a rule to govern a dispute in tort, contract, or property that involves as many as thirty-eight parties should assume that the parties can and will exhaust the gains from trade by voluntary agreement. One who would show that bargaining breakdown is likely must bear the burden of proof.

$* * *$

Regardless of the ultimate success of the arguments for and against Posner's version of the economic efficiency criterion [ ], our experimental results should affect the tenor of the arguments: One who is arguing for the use of the efficiency norm may now claim that the norm describes what parties to a bargain will decide to do for themselves. The judge, then, is simply facilitating an inevitable process and is justifiably concerned about promoting economic efficiency. By simply choosing the efficient outcome, the judge merely saves society the legal costs that would be incurred during a long bargaining process. ${ }^{18}$

The authors offer some applications of their conclusion. The first application is to nuisance cases. They describe a hypothetical case involving a dispute between the owner of a dog kennel and some neighbors:

Our results suggest that the choice should be between [an injunction for the plaintiffs, or a property right for the kennel owner, rather than damages payable by either side,] because risk of breakdown in voluntary negotiations is ordinarily low, perhaps even if there are as many as thirty-eight parties to the dispute. Where the kennel is not enjoined as a nuisance, then the homeowners can by agreement pay the kennel operator money to reduce the pollution. Where the kennel operation is so enjoined, the optimal level of pollution can be achieved, this time with payments from the kennel operator to the homeowners. ${ }^{19}$

\footnotetext{
${ }^{18}$ Id at $151,170$.

${ }^{19}$ Id at 164 . The authors note that "[t]he strength of these results may depend in part on the nature of the participants to the dispute. If the homeowners are relatively homogeneous in their income and preference, the dispute may be more easily resolved than it would be if they differed among themselves in these respects." Id at 163-64.
} 
I mean to have said just enough to indicate two things: the paradigmatic role that nuisance cases have played in economic discussions of when property rights and liability rules ought to be used; and the mental picture of nuisance cases and the behavior of the parties to them after judgment that generally has informed those discussions. I will not try in this Article to say whether property rights or liability rules are superior as remedies in any particular circumstance. Rather, my purpose here is to examine some actual nuisance cases and their aftermath and discover whether they resemble the stories told in the economic literature. We do not know whether parties to nuisance cases really do bargain after judgment. If and when they do not, we do not know why. We do not know whether the important obstacles to bargaining are the problems of coordination and strategic behavior that dominate the economic literature, or whether other aspects of the norms, attitudes, or circumstances confronting the parties may cause them to treat a court's judgment as final. A growing literature explores ways in which human behavior may depart from economists' conventional expectations, whether on account of the "endowment effect," constraining norms, or other psychological or sociological considerations. ${ }^{20}$ This Article aims to contribute to that project by presenting accounts of how actual litigants have behaved in a setting that has been the subject of much conjecture.

\section{METHODOLOGY}

In setting out to learn whether the behavior of parties to real nuisance cases after judgment resembles the behavior envisaged in the literature, I began by searching online databases of reported judicial decisions for recent nuisance cases that involved simple, classic fact patterns-the sort of cases Coase used to illustrate his argument in The Problem of Social Cost, and that have been the subject of so much subsequent consideration. In particular, I sought cases that appeared to involve low transaction costs by conventional standards: disputes between private parties where practical impediments to bargaining-such as coordination and holdout problems-seemed low, so that it was plausible to suppose that the parties could bargain around the court's judgment if they wanted to do so. I used cases that ended with the award of a property right to one side or the other, be-

\footnotetext{
${ }^{20}$ These phenomena, and their relationship to this study, will be taken up in more detail later. For an overview and references, see Christine Jolls, Cass R. Sunstein, and Richard Thaler, A Behavioral Approach to Law and Economics, 50 Stan L Rev 1471 (1998).
} 
cause those are the cases Coase and others most often have discussed; because those are also the cases most often said to present a likely occasion for bargaining after judgment; and because property rights are the most common remedies in nuisance cases.

To state the specific criteria for selecting the cases, then, they had to involve ongoing private nuisances: lawsuits arising from conduct of one neighbor that typically was bothersome to the eyes, ears, or nose of another. They had to involve few parties: suits involving just two neighbors, or perhaps a handful of families living near each other-and in no case involving more than forty people. ${ }^{21}$ They had to be cases in which a court entered a final judgment consisting of a property right for one side or the other (an injunction or a judgment of no liability for any reason). ${ }^{22}$ They had to be cases where there were no other claims between the parties, or at least none that were entangled with the nuisance claims; for example, I avoided the many cases where the plaintiff complained that the defendant was committing zoning violations as well as creating a nuisance, since a successful claim of a zoning violation by the defendant would foreclose the possibility of bargaining after judgment between the parties. ${ }^{23}$ And I looked for cases several months old (to give the parties time to bargain) but preferably not older than a year (so that the cases would still be fresh in the minds of the lawyers who handled them). I located twenty cases that fit all these criteria. ${ }^{24}$ All in-

21 This number is approximately the cutoff at which Hoffman and Spitzer have expressed confidence that bargaining feasibly can occur. Hoffman and Spitzer, $15 \mathrm{~J}$ Legal Stud at 162, 171 (cited in note 4). The criterion was easy to satisfy: simple nuisance disputes involving more than thirty people are rare, at least in the published opinions.

${ }^{2}$ This criterion, too, was easy to satisfy. Courts rarely limit successful nuisance plaintiffs to damages, and so far as I have been able to determine, the "Rule 4 " remedy described by Calabresi and Melamed, see 85 Harv L Rev at 1115-24 (cited in note 2), has not been used in any reported nuisance case since it was introduced in Spur Industries, Inc $v$ Del E Webb Development Co, 108 Ariz 178, 494 P2d 700 (1972). Compare Joel C. Dobris, Boomer Twenty Years Later: An Introduction, With Some Footnotes About "Theory", 54 Albany L Rev 171, 180 (1990) (describing the compensated injunction as "a novelty item from some academic rubber goods catalog"), with A. Douglas Melamed, Remarks: A Public Law Perspective, 106 Yale L J 2209 (1997) (arguing that "Rule 4" remedies are widely used in public law contexts).

${ }^{23}$ I did not necessarily discard a case, however, if the zoning claims failed and the nuisance claims were sufficiently prominent, since bargaining would then remain a possibility. See, for example, Sedman v Rijdes, 127 NC App 700, 492 SE2d 620 (1997), and Karpiak v Russo, $450 \mathrm{~Pa}$ Super 471, 676 A2d 270 (1996). Both cases are described and discussed in the appendix.

${ }^{24}$ Actually I located a few more cases than that, but I will only discuss twenty of them here. My initial inquiries were somewhat open-ended; I knew that I wanted to discover what happened after judgment, but I wasn't sure what questions to ask the attorneys, and my resulting notes were not sufficiently complete to warrant their inclusion as case studies. However, my preliminary investigations suggest that none of the omitted cases in- 
volved appeals, since those tend to be the cases that generate reported decisions in the state courts. Most involved disputes between two homeowners or between a homeowner and a small business, usually owned and run by one person or a family. ${ }^{25}$ Later I will discuss some of the limitations of this methodology. ${ }^{26}$

After identifying these cases, I contacted the attorneys of record, seeking to interview them either by telephone or in writing (or both) about what happened between the parties after judgment. Usually I communicated with lawyers for both sides (and told each of them that I was doing so). All of the lawyers I was able to reach were willing to talk about their cases. ${ }^{27} \mathrm{I}$ asked whether the rights the court awarded had changed hands after judgment, and if not, whether there were any negotiations over that possibility. If there were no negotiations, I asked why not, and whether the lawyers thought there would have been bargaining after judgment if the court had decided the case the other way (that is, if the loser had won). This last question was important, because it addressed the possibility that if there was no bargaining it was only because the court had assigned a property right to the side that would have paid the most for it anyway. The implication of such an assignment is that if it had been made the other way-in other words, if the loser had won-then the loser would have bought the rights from the winner, or at least would have tried.

volved patterns that differ from the cases included in this Article. The excluded cases are Aldridge v Morgan, 912 SW2d 151 (Tenn App 1995); Benjamin v Nelstad Materials Corp, 214 AD2d 632, 625 NYS2d 281 (1995); Kearney $v$ Barrett, 1995 Tenn App LEXIS 4; Goeke v National Farms, Inc, 245 Neb 262, 512 NW2d 626 (1994); LeFurgy v Long Cove Club Owners Association, Inc, 313 SC 555, 443 SE2d 577 (SC App 1994).

${ }^{25}$ Ten of the cases involved disputes between homeowners; ten involved a business on at least one side of the case. Just one involved small businesses on both sides: 44 Plaza, Inc v Gray-Pac Land Co, 845 SW2d 576 (Mo App 1992). The division of the parties into homeowners and businesses is rough. First, it sometimes is difficult to classify cases if they involve homeowners engaged in low-level business activities. Examples include Tichenor $v$ Vore, 953 SW2d 171 (Mo App 1991), in which the defendant kept several dogs on his property with the eventual intention of showing and selling them, and Miller $v$ Horn, 1996 Ohio App LEXIS 2678, in which the defendant was an old woman operating a motel for cats. Second and more generally, the businesses involved in these cases, whether or not they were incorporated, were relatively small, usually owned and run by one person or by a family. As a result, the differences between these types of parties were not large. Nor, as we shall see, did there tend to be important differences in their behavior. Perhaps because old-fashioned nuisance disputes often arise in unincorporated areas where zoning rules do not do much work, or perhaps for other reasons that I will discuss later, none of the simple nuisance cases that fit the criteria just described were brought against large corporations.

${ }^{26}$ See discussion in Section $V$.

${ }^{27}$ In all, I communicated by telephone, mail, or both with lawyers for both sides in sixteen of the cases. In the other four cases I relied on one side's account. 


\section{RESULTS}

To summarize the reports the lawyers offered in response to these inquires, none of the parties in the twenty cases made trades after judgment. They generally did not negotiate at all after judgment. ${ }^{28}$ Nor did the lawyers in these cases think there would have been bargaining if the litigation had ended with a judgment in the opposite direction.

Two impediments to bargaining after judgment figured prominently in the lawyers' reports. First, in almost every case the lawyers said that acrimony between the parties was an important obstacle to bargaining. The parties in these cases often thought that their adversaries were behaving in ways that were unreasonable, discourteous, and unneighborly. Frequently the parties were not on speaking terms by the time the case was over (sometimes much earlier). ${ }^{29}$

The second recurring obstacle involves the parties' disinclination to think of the rights at stake in these cases as readily commensurable with cash. The lawyers often would say that their clients "didn't want money. They wanted to get rid of the noise" created by the defendants; or that the "money wasn't important" to their clients in this context; or that the "[t]he case had to do with your right to use your land as you damn well please"; or that the lawyer's clients "weren't out to make a buck over the whole. thing. They were concerned about their rights." Other lawyers remarked on the difficulty their clients would have had in putting a price on the rights at issue in the case. On reflection, the attorneys would concede that their clients might have been amenable to a cash bargain if the price were extraordinarily attractive, but they said that no such price would have been offered by either side.

One of my goals in this Article is to offer a realistic picture of the attitudes of parties to nuisance cases that are litigated to judgment and of their behavior afterwards. Here I will describe five illustrative cases. (The other fifteen are described in the ap-

\footnotetext{
${ }^{23}$ Occasionally a proposal of some sort was suggested by one side and dismissed by the other after judgment. See, for example, Slavant $v$ Calhoun Motor Speedway, 626 S2d 771 (La App 1993), described and discussed in the text accompanying note 101. In no cases were there reports of substantial negotiations.

${ }^{29}$ Possible exceptions are BAGKO Development Co $v$ Damitz, 640 NE2d 67 (Ind App 1994) (see text accompanying note 37), which involved parties described by their lawyers as "hard-headed," but who apparently got along all right, and Langan $v$ Bellinger, 611 NYS2d 59, 203 AD2d 857 (1994) (see text accompanying note 109), which involved complaints about a church's bells, and in which it was not clear whether acrimony was an important factor.
} 
pendix.) These cases are representative just in the sense that they present nicely the kinds of problems the lawyers regularly described. They also represent a mix of disputes between individuals on the one hand and between individuals and small businesses on the other.

Thomsen $v$ Greve. ${ }^{30}$ The Thomsens (Elmer and Phyllis) and the Greves (Ron and Nancy) are neighbors in Pender, Nebraska. The Greves moved there in 1973; the Thomsens moved in next door in 1990. In 1986, the Greves started using a wood-burning stove as their primary means of heating their house. In 1992, the Thomsens began complaining to the Greves that smoke from the stove was finding its way into their house, bringing "rotten," "unbearable" smells with it and making the Thomsens physically ill. ${ }^{31}$ The Greves suggested that the Thomsens keep their windows and doors shut. Eventually the Thomsens filed a lawsuit seeking to enjoin the Greves' use of their stove as a nuisance. The trial court denied the Thomsens damages, but ordered the Greves to increase the height of their chimney by thirty-six inches; the court of appeals reversed in part, awarding damages and ordering the Greves to abate the nuisance, regardless of whether this could be accomplished by extending the chimney. On remand, the trial court modified the injunction to allow the Greves to use their stove when the wind was from the west, southwest, or northwest at a rate of at least ten miles per hour, which would be sufficient to blow the smoke away from the plaintiffs' house.

The lawyers reported that after judgment the defendants stopped using their stove altogether rather than try to adapt their use to the conditions the court had set. There was no discussion after judgment of the possibility that the defendants might pay the plaintiffs for the right to continue using their stove as before; negotiations "did not occur because the defendants are the most unreasonable people in the community" (according to the plaintiffs' lawyer) or because "hard feelings resulting from this litigation prohibited any reasonable resolution" (according to the defendants' lawyer).

The lawyers for both sides agreed that if the defendants had won the case, there likewise would have been no bargain struck in which the plaintiffs paid the defendants not to use their stove: "if the court had found no nuisance, the defendants would have

\footnotetext{
${ }^{30} 4 \mathrm{Neb}$ App 742, 550 NW2d 49 (1996). This account is based on the opinion in the case, questionnaires filled out by both lawyers, and telephone interviews with the lawyers for the plaintiffs and the defendant (Feb 11, 1998).

${ }^{31} 550 \mathrm{NW} 2 \mathrm{~d}$ at 52-53.
} 
continued burning garbage and whatever else they burned." "The feelings in the matter were such that nothing was going to end this dispute short of ridiculous sums of money changing hands to buy the other side's house," the defendants' lawyer said. The plaintiffs' lawyer had a similar view of the situation. "They hate each other. They'll flip each other off as they drive by." The plaintiffs' lawyer had heard that the Greves' defense was financed by their homeowners' insurance company, which he thought must have spent more than $\$ 30,000$ on the case. I asked him whether the plaintiffs would have accepted $\$ 30,000$ in cash to settle the case, and he said probably yes; but no such offer was made. At one point, the defendants did offer to buy the plaintiffs' house outright for the price the plaintiffs had paid to acquire it, but the plaintiffs "weren't interested in moving" and the defendants weren't interested in paying the plaintiffs a sum large enough to dislodge them.

Tichenor $v$ Vore.$^{32}$ Carl Vore lives near Wheaton, Missouri, a semi-rural area; his house is just beyond the official town line, in an unincorporated region. He raises dogs for the eventual purpose of showing them and selling them. Next to his house he built a kennel in 1995. Constructed of cinder blocks and a wood shingle roof, the kennel served to house his Australian Sheperd show dogs. The kennel contained pens for the dogs and "runs" along its sides where they could be exercised. He kept about sixteen dogs there.

Five neighboring families brought a nuisance suit against Vore, complaining about the barking of the dogs. Charles Tichenor, the lead plaintiff, testified that Vore's dogs would "[b]e barking hard enough, constant enough, you can't go back to sleep ... you lay there and listen to them dogs. ${ }^{, 33}$ At trial Tichenor also said that he had been a "royal grouch" for the past year; "[t]he dogs has finally just got me-my nerves shook. There ain't no place to get away from it." Tichenor's wife put into evidence a fifty-page typewritten diary of the aggravation the barking caused her and her husband. The Tichenors said they "were often unable to perform yard work, plant flowers, work in the garage or enjoy their back porch because of the constant 'roar' of dog barking. ${ }^{.34}$ Other neighbors who lived nearby, though not quite as

${ }^{2} 953$ SW2d 171 (Mo App 1997). This account is based on the opinion of the case, a questionnaire filled out by the defendant's lawyer, and a telephone interview with the plaintiffs' lawyer (Mar 13, 1998).

${ }^{3}$ Id at 175.

${ }^{34}$ Id. 
close as the Tichenors, testified to substantial but lesser degrees of annoyance.

The trial court entered an injunction against the operation of the kennel, permitting Vore to keep just two dogs. The court of appeals affirmed. Since then, the injunction has been enforced; there have been no discussions between the parties of the possibility that Vore might purchase from the defendants the right to continue housing his dogs in the kennel. The plaintiffs' lawyer predicted that if Vore had made such overtures, his clients would have said "not only No' but 'Hell, no: get your dogs out of there." Mr. Vore's lawyer agreed: the plaintiffs "would not have agreed to do anything for the benefit of the defendant for any amount of money." But what if Vore had won the case-would the plaintiffs have paid him to get rid of the dogs? Both lawyers thought not. "It was obvious that both sides were pretty strong-willed," the plaintiffs' lawyer said; he thought that offers to pay Vore "would have fallen on deaf ears." "Money wasn't important to [Vore]. The case had to do with your right to use your land as you damn well please," he said.

The plaintiffs' lawyer compared this case to others where a landowner builds a fence ten feet over his neighbor's property line. In these situations, he said, one might think the land would be easy to value and that a deal might be struck, but in his experience this was not so: "generally the emotions are so strong, they're almost like the emotions in a divorce, because it's land involved that's dear to their hearts"- "particularly in rural Missouri, where land is important."

This is not to say that there has been no movement at all on Vore's side. Though he has not been negotiating with the plaintiffs, he has been considering other ways that he might be able to avoid trouble under the injunction and still bring back his dogs. His lawyer wrote that "Mr. Vore is deciding whether to have his show dogs 'de-barked' (a surgical procedure of severing the vocal chords, thereby reducing the bark of the dog to a whisper)."

Payne $v$ Skaar.$^{35}$ Idaho Falls is a town on the Snake River in Idaho populated by about 50,000 people. In 1971 Keith Skaar bought a cattle feedlot on the north side of the town. At the time it contained between 500 and 1,000 cows. The number grew to 5,000 by 1990 . Neighbors living in homes nearby became un-

${ }^{35} 127$ Idaho 341,900 P2d 1352 (1995). This account is based on the opinion in the case and on telephone interviews with the lawyers for the plaintiffs (May 21, 1996) and defendants (Sept 12, 1996). 
happy with the smell. About ten couples and a few others in the neighborhood established an organization dedicated to eradicating the feedlot. They sued Skaar, his wife, and the corporation they had formed. On the recommendation of an advisory jury, the judge entered an injunction ordering Skaar to make various improvements in sanitation and to reduce the number of cows to the level that he maintained prior to the complaints. After an enforcement proceeding (and an unsuccessful appeal by Skaar on several essentially technical grounds), the feedlot went out of business. Skaar blames the lawsuit.

The lawyers agreed on the following points: there were no discussions between Skaar and the plaintiffs, or among the plaintiffs, about the possibility that Skaar might pay them for permission to continue operating his feedlot at full strength. There would have been no interest in such a transaction if it had been suggested. The lawyers said that the plaintiffs did not want to be bought out. They were focused on getting rid of the smells the feedlot created, and did not think of the situation in terms of money. In their view, Skaar in effect was dumping manure onto their property without permission; they considered him a bad neighbor whose discourtesy was offensive. The plaintiffs' lawyers described the suit as a "contest of wills." The residents pressed hard for the enforcement of every line of the injunction, even when it became clear that Skaar could not feasibly comply; Skaar's lawyer thus concluded that the basis for the suit was "vendetta" rather than principle, and for that reason he agreed with the plaintiffs' lawyers that negotiations to temper the terms or enforcement of the injunction would have been futile.

If Skaar had won, would the neighbors have paid him to scale back his feedlot? The lawyers thought not; they described it as a "neighborhood dispute" with too much bad blood to be overcome. From the plaintiffs' perspective, Skaar would have been too stubborn to accept a deal; "people were threatened with firearms and shovels at times" and Skaar was a "truculent, obdurate man." From the defendant's perspective, in addition to the problems created by the personalities involved, Skaar was uninterested in taking money to scale back. He was trying to grow his business, and he claimed it would cost him a million dollars to relocate.

Ball $v$ Jorgenson. ${ }^{36}$ Mrs. Ball owned property adjacent to land owned by a family named Jorgenson in Josephine County, Ore-

${ }^{35} 147$ Or App 55, 934 P2d 634 (1997). This account is based on the opinion in the case, 
gon. A stream ran through the Jorgensons' property on a seasonal basis, and when flooding became heavy, their horses were in danger of contracting "hoof rot" from standing in water. The Jorgensons therefore dug ditches to channel the water diagonally across their property line and onto Mrs. Ball's land (some of the water already flowed in that direction, but the ditches increased and intensified the flow of water onto her property). Mrs. Ball used piles of dirt to block the flow of the water, and she brought a lawsuit seeking to enjoin its diversion onto her land (she wanted the flow restored to its state before the ditches were added); the Jorgensons counterclaimed for an injunction requiring Mrs. Ball to remove the dirt she had placed in the water's path. The trial court found for the Jorgensons. The court of appeals affirmed on the ground that Mrs. Ball's trial lawyer had not objected properly at trial to the jury instructions that were the subject of the appeal.

Mrs. Ball did not go on to pay or otherwise induce the Jorgensons to stop channeling the water onto her property. The lawyer who handled her appeal wrote that "my impression was that trial counsel on both sides had little or no client control. The parties were so polarized by trial that any compromise postjudgment was impossible." He said that the parties "disliked each other intensely," and he thought this might have been an aberration caused by some unique features of Josephine County in southern Oregon, a region he described as heavily populated with "survivalists and crazy right-wingers" who are "retreating from something," are "very intolerant of their neighbors," and "take an extreme view of property rights." "I really feel that the litigants couldn't be expected to reach an agreement, not because it wouldn't have been reasonable, but because their views were so extreme." Mrs. Ball's lawyer said the parties' positions were made more intractable by the defendants' failure to ask the plaintiff for permission before diverting the water onto her land; he said that in this region, incursions by one property owner onto the land of another sometimes seemed to ignite "something akin to 'road rage'-people just snap." He thought that had happened here, and said that the negotiations that did occur before judgment consisted of "histrionics on both sides."

The lawyers did not think there would have been bargaining if Mrs. Ball had won. The defendants' lawyer said he thought his clients would have been ready to make an offer to Mrs. Ball, but he thought "she would not have accepted anything"; he charac- 
terized her as "exceptionally hard-headed," and said that settlement discussions had not been fruitful: she "wrote long, scathing letters saying she recognized no authority but the Lord." Mrs. Ball's appellate lawyer likewise said that "she would have planted her feet" if she had won and would not have authorized him to negotiate. The appellate lawyer thought that there might have been an opening for a compromise of some sort if the case had been remanded for retrial, because then he would have taken over the case from the previous trial counsel, and he had a good relationship with the lawyer on the other side of the case. $\mathrm{He}$ thought that perhaps he and the other lawyer could have persuaded the parties to accept some sort of agreement rather than go through another trial. But he said that a victory for either side, as occurred here, foreclosed the possibility of negotiations.

BAGKO Development Co $v$ Damitz. ${ }^{37}$ A building company called BAGKO, owned by a man named Bagley and run by Bagley and his son, bought property in Kokomo, Indiana and developed a subdivision there called Willowridge. The first buyers in Willowridge were Charles and Nila Damitz. They had three young sons; Charles Damitz was a little league baseball coach. In addition to the lot for the house, the Damitzes bought a neighboring parcel of land and spent about $\$ 45,000$ building a regulation-size baseball diamond there. The diamond included lights, a pitching machine, and a batting cage, and Mr. Damitz used it to coach two teams from 4:00 until 7:30 p.m. two or three times a week from April through June. Some other children from the neighborhood played whiffle ball and other games on the diamond during the offseason. There were no reports of balls flying onto anyone else's property.

Mr. Damitz said that he obtained permission to build the baseball diamond from the junior Bagley, who had agreed to allow it because Damitz had agreed to buy an expensive lot and build an expensive house there. But when the senior Bagley learned of this arrangement he strongly disapproved. He believed that the property in the development should be used for residential purposes only, and along with a resident who lived next door to the diamond, he sued Damitz on nuisance and other theories. (In fact nine residents of Willowbrook complained about the lights from the diamond; for eight of them, however, it was

\footnotetext{
${ }^{37} 640$ NE2d 67 (Ind App 1994). This account is based on the opinion in the case and on telephone interviews with the lawyers for the plaintiff (May 22, 1996) and defendants (May 22, 1996).
} 
enough that Damitz agreed to reduce his use of the lights.) Damitz offered to take down the lights on the field altogether to get rid of the complaints from the remaining resident and from Bagley, but Bagley was adamant that the diamond must go. After a two-day bench trial, the court gave judgment to the Damitzes, finding among other things that the baseball diamond was not a nuisance; the court of appeals held this not to be clearly erroneous.

There were no negotiations after judgment. The baseball diamond remains in place. Mr. Damitz gets along with his neighbors, and by all accounts he is reasonable in his dealings with the Bagleys (aside from the matter of the diamond). Both lawyers characterized the parties as "hard-headed," and did not think negotiations after judgment would have gone anywhere, no matter who had won the rights in court. If Bagley won, the diamond would go (and presumably the land would be sold to someone else). The lawyer noted that Bagley did not ask for damages. $\mathrm{He}$ wanted an injunction or nothing. If Mr. Damitz won, the ballfield would stay (and has stayed). Mr. Damitz was unwilling to consider selling out to Bagley, his lawyer said, because he felt that he had been promised he could have the diamond, and it meant a lot to him.

\section{INTERPRETATION AND IMPLICATIONS}

The sample of cases considered here is too small, and the methodology too informal, to support aggressive generalizations about how courts should resolve nuisance disputes. But the consistency of the results in these cases is striking, and seems sufficient to support a more modest conclusion: stylized economic descriptions of nuisance litigation and its aftermath have omitted consequential dimensions of human attitudes and behavior. The omissions are important because they have caused the models to generate potentially misleading predictions about behavior after judgment. So while it is not possible to say that parties never bargain after judgment in nuisance lawsuits, it is possible to say that there are serious and potentially fatal obstacles to bargaining after judgment-obstacles that deserve consideration in the literature of remedies, and that courts interested in efficiency ignore at their peril.

This Section examines those obstacles. First I discuss ways in which parties' acrimony and their disinclination to treat the rights at stake as commodities may eat away any bargaining range that otherwise might exist between them. Next I examine the extent to which those obstacles to bargaining after judgment 
may be related to the absence of markets for the rights at stake in nuisance cases. Then I will consider whether the obstacles discussed here properly should be considered to be transaction costs; lastly, I will argue that the results of this study illustrate the need for more particularity in economic models if they are to generate useful advice.

\section{A. The Destruction of Bargaining Ranges by Acrimony and}

Resistance to Commodification

Begin with an economic restatement of what the lawyers described. They commonly said that no amount of money would have been enough to dislodge the rights from the winners-no matter who won. On further examination the attorneys routinely would concede that of course some amount of money would have been enough to pry the rights away from the winner; it just would have to have been an astronomical amount that the loser would not have considered paying. (Or the converse: the loser did not want to buy the rights from the winner, but might have come around if the winner practically were giving the rights away.) In effect, for the winners in these cases to sell their rights to the losers, the losers would have been required to pay the winners a premium to cover the distaste both of doing business with their adversaries and of doing business at all in rights over which they did not want to bargain. A price exists at which the winners might have sold their rights to the losers, but for the enmity between them. The amount required to be added to that price in order to get the winner to hold its nose and make the deal might be called an acrimony premium. Similarly, the winner might have accepted a certain price but for its aversion to exchanging cash for the rights at stake in the case; the extra amount the loser would have to pay to make the winner forget about that aversion is a premium of another sort-perhaps a commensurability premium. ${ }^{38}$

The size of the premiums the winners would have demanded is then magnified by the losers' likely lack of interest in paying them. On the contrary: the losers want to be paid the premium amounts, too. They may bring as much ill will to the table as the winners do, and they may find the idea of a cash exchange as dis-

${ }^{39}$ See, for example, Cass R. Sunstein, Social Norms and Social Roles, 96 Colum L Rev 903, 943-44 (1996) (suggesting that people may be unwilling to accept money as compensation for allowing a disagreeable outcome that is not normally measured in monetary terms; if they do accept money, they may demand large premiums to compensate for the shame of entering the transaction). 
tasteful as the winners do. In either case, the losers would only be interested in making an exchange if the price were reduced to an extent so irresistible that they were shaken out of their reluctance to deal. So the premiums just described have the unusual property of both driving up the price the winner would be willing to accept and driving down the price the loser would be willing to offer-regardless of who wins and loses. In a case where these premiums are substantial, it is easy to see how they may destroy any bargaining range that otherwise might have existed between the parties' positions. They are termites that have the potential to devour any surplus that might otherwise be created by a court's decision one way or the other.

Any general illustration of the problem will be artificial because the idea of an acrimony premium distinct from the rest of a party's valuation is strained. But imagine nonetheless that A would be willing to pay $\$ 600$ for the rights at issue in a case, and $\mathrm{B}$ would be willing to pay $\$ 1,000$. These, however, are the amounts they would be willing to bid at an auction, not necessarily in a different setting. Now suppose $A$ is awarded the rights by a court, apparently creating a $\$ 400$ bargaining range. But $\mathrm{A}$ and $B$ come to detest each other. A's general view, though thinly articulated, is that he won't sell the rights to B at any price, and B's sense - also largely inarticulate, but firmly held-is that he'll be damned if he's going to crawl back to $A$ to offer him even a dime for the rights. A would set his hard feelings to one side if the offer were large enough-if it were $\$ 5,000$ (suggesting an acrimony premium of $\$ 4,400$ ). Likewise, B probably would consider paying A for the rights if the offer were stupendously low-say, $\$ 50$. So there will be no bargain; the bargaining range is smaller than the sum of the acrimony premiums due from each side. It might be different if $A$ and $B$ each just needed an extra $\$ 150$ to get over their disinclination to do business with each other; then the $\$ 400$ apparent bargaining range would be reduced but not eradicated, with $\$ 150$ being added to the amount $A$ demands, and $\$ 150$ being subtracted from what B is willing to pay. And in cases with sufficiently high stakes (higher than those typically found in an ordinary nuisance case), the bargaining range between the parties' positions may be large enough to allow gains from trade even after the subtraction of substantial acrimony premiums. The example is no different, so far as the economics are concerned, if the disinclination to bargain is large but is completely one-sided (for example, one of the parties is a hothead, but the other is a corporation that may not much care who it bargains with), or if the 
force at work is not acrimony but a distaste for cash exchanges in the context at hand.

These phenomena bear some resemblance to the often observed and more general difference between what people may be willing to pay for a good and what they may demand for it if it belongs to them. ${ }^{39}$ Indeed, the results in this study might be considered a species of the endowment effect, ${ }^{40}$ which is one account of the distinction between willingness to pay and willingness to accept. One way to interpret these cases and the lawyers' views of them is to say that a strong endowment effect attaches to judgments from a court. One has to be careful in offering the endowment effect as an explanatory tool, however, since the concept can be defined and used in a number of different ways. Strictly speaking, the endowment effect does not refer to just any difference between what a party would offer for a good and what a party would demand for it. It refers to the increased value a person may assign to a good just because they own it-because, in other words, it has become part of their "endowment"1 - though the phenomenon also has been shown to be correlated with certain other attributes that goods may have, such as uniqueness. ${ }^{42}$ In any event, I believe that the parties' valuations in these cases exhibit a similar pattern, but for reasons that are more complicated and that are rooted more deeply in the details of the contexts in which the parties' disputes arose than the fact that one of them owns the rights and the other does not. Specific features of the parties' relationships to each other, and of their relationships to the rights at stake in their disputes, made bargaining unappealing.

\footnotetext{
${ }^{39}$ See generally Don L. Coursey, John L. Hovis, and William D. Schulze, The Disparity Between Willingness to Accept and Willingness to Pay Measures of Value, $102 \mathrm{Q} \mathrm{J}$ Econ 679 (1987); W. Michael Hanemann, Willingness To Pay and Willingness To Accept: How Much Can They Differ?, 81 Am Econ Rev 635 (1991); Elizabeth Hoffman and Matthew L. Spitzer, Willingness to Pay vs. Willingness to Accept: Legal and Economic Implications, 71 Wash U L Q 59 (1993); Daniel Kahneman, Jack L. Knetsch, and Richard H. Thaler, Experimental Tests of the Endowment Effect and the Coase Theorem, $98 \mathrm{~J}$ Pol Econ 1325 (1990). For discussions that use this phenomenon to critique economic analysis, see Mark Kelman, Consumption Theory, Production Theory, and Ideology in the Coase Theorem, 52 S Cal L Rev 669, 685-95 (1979); Duncan Kennedy, Cost-Benefit Analysis of Entitlement Problems: A Critique, 33 Stan L Rev 387, 401-21 (1981).

${ }^{40}$ See Richard Thaler, Toward a Positive Theory of Consumer Choice, $1 \mathrm{~J}$ Econ Behav \& Org 39, 43-47 (1980). See also Kahneman, Knetsch, and Thaler, $98 \mathrm{~J}$ Pol Econ at 1325 (cited in note 39) (discussing endowment effects in bargaining over legal rights); Richard H. Thaler, Quasi Rational Economics 184 (Russell Sage 1991) (specifically noting that "[t]he existence of the endowment effect reduces the gains from trade").

"See Thaler, Quasi Rational Economics at 169 (cited in note 40).

${ }^{42}$ See id at 167-88.
} 


\section{B. The Function of Markets}

I want now to explore the possibility that the practical and cognitive obstacles to bargaining just discussed might be understood as resulting from the absence of vigorous markets for the rights typically at stake in nuisance cases. By an absence of vigorous (or "thick") markets, I am referring to the fact that the parties in these cases were able to deal only with each other and that there often were no good substitutes for the goods involved in their disputes. In a robust market (as I will use the term), there is competition for goods and they have ready substitutes. ${ }^{43}$ In suggesting that the lack of bargaining in these cases may be related to the absence of markets for the rights involved, I am not referring only or even primarily to the problems usually thought to be presented by thin markets, such as the possibility that an absence of competition might permit both sides to hold out for payments much greater than their true reservation prices. The obstacles to bargaining presented in these cases-or at least those problems in the forefront of them-do not appear to involve strategic behavior or the fear of it. Rather, I argue that markets may reduce the incidence and significance of the acrimonious attitudes of the parties in these cases, and that markets bring with them (and are made possible by) a set of values and a way of thinking about entitlements that the parties in these cases did not share. The cognitive and normative function of markets, as well as their practical function, is to encourage the kinds of transactions that did not occur after judgment in these cases.

\section{Acrimony.}

The first obstacle to bargaining the lawyers identified was acrimony, grudges, or bad chemistry between the parties; lawyers who had handled a number of nuisance cases sometimes remarked on their "rancorous" nature and on the rancorous nature of property litigation between neighbors generally. If two people are not on speaking terms, it may seem easy enough to understand why they do not bargain. On reflection, however, it might

${ }^{4}$ See Ian Ayres and F. Clayton Miller, "Tll Sell It to You at Cost": Legal Methods to Promote Retail Markup Disclosure, 84 Nw U L Rev 1047, 1058 n 43 (1990) (defining a "thick market" as "one in which parties publicly trade so many homogeneous products that a well-developed spot price is readily available"); David D. Haddock, Jonathan R. Macey, and Fred S. McChesney, Property Rights in Assets and Resistance to Tender Offers, $73 \mathrm{Va}$ L Rev 701, 706 (1987) ("Thick markets are characterized by frequent transactions of nearly homogeneous units."); Jeffrey Standen, The Fallacy of Full Compensation, 73 Wash U L Q 145, 223 n 298 (1995) (contrasting a "thick market,' where substitution is readily available, and [a] 'thin market,' where it is not'). 
seem a little odd that ill will should play an such important role in the parties' unwillingness to bargain, since the parties had lawyers to handle their negotiations, and in some business contexts parties may bargain despite not liking each other at all. Why is acrimony so important here?

Perhaps the answer has to do with the function of markets and their absence in these cases. As a practical matter, markets make transactions quicker. They reduce the need for personal interaction between buyers and sellers and usually eliminate the need for buyers and sellers to be in close proximity either before or after their business is done. Vigorous markets thus tend to make transactions less personal and more faceless; purchasers are focused on what they are buying, not the identity of the seller. Neighbors in nuisance disputes do not have those advantages. Judgment arrives after a long series of previous moves between the parties-antagonistic moves, if the parties are litigating. And while the parties may have lawyers who can bargain on their behalf, this only avoids one sort of face-to-face contact between them. They enjoy no anonymity of any other sort, and they usually will have to assume that they are stuck with each other for the foreseeable future. The identities of the buyers and sellers are uppermost in each others' minds.

The nature of the right makes it still more difficult to separate from the person selling it. A bargain after judgment in a nuisance case often would resemble a kind of personal service contract-a contract in which one party agrees to perform or not perform some activity, rather than a contract that provides for the simple exchange of a thing. It is harder to depersonalize this kind of service contract than a contract for goods, because the subject of the contract is the seller's own behavior. The rights involved in these nuisance cases were also personalized on their other endthe receiving end, as it were. Where the issue is the allocation of a simple good, one party can end up with it and the other can move on. Here, the right at stake consists in part of one neighbor's right to inflict disutility on another. It is not just A's right to a given stick in the bundle that is at issue; it is A's right to poke B with it.

Sometimes a lack of anonymity between parties to a bargain can be an advantage, of course, as in situations where one neighbor makes an "off-market" transaction to sell some property to another when they are on friendly terms, or where a budding nuisance dispute is nipped with a phone call to the neighbors asking them to turn the music down. The bargain in turn may even improve their relationship; it may amount to an exchange of 
favors that adds to the good will between neighbors. Bargains outside of markets thus may have communicative components and other meanings that robust markets might otherwise have diluted. But of course not everyone is equally accommodating, and inevitably some neighbors will be radically unaccommodating. (And one neighbor who is perceived as falling into that category may incite others to follow suit.) In these instances the personalization of the bargain, and the side meanings it connotes, can become a great disadvantage. A bargain requires a compromise, which often will entail a show of respect for the importance of another's interests. That respect may be wanting. Either party may be eager to avoid making the other better off.

Finally, strong markets may soften the impact of prickly people even in situations where the parties to an exchange do care a lot about the identities of their trading partners. Those who feel strongly about their partners can choose among many; the significance of their idiosyncrasies likely will be washed out by the offsetting idiosyncrasies of others. If the parties' views of each other are not idiosyncratic-in other words, if a player earns a general reputation as a bad egg-the bad egg will be punished by the market and perhaps driven out of it altogether. And in a pinch there may be possibilities for arbitrage:44 an intermediary can do business with each of the parties without their needing to do business with each other. ${ }^{45}$ But in a neighborhood nuisance dispute, the significance of prickles and other idiosyncrasies is magnified. There is no market that can punish and thus curb the expression of temperamental inflexibility; likewise there is no market into which one can escape by resorting to other buyers or sellers.

\section{Distaste for bargaining.}

The other thread that runs persistently through the lawyers' accounts is that their clients would have found the prospect of a cash exchange altogether distasteful, apart from the identity of the partner to the exchange. The precise nature of this distaste is difficult to pinpoint, since it often was expressed imprecisely in remarks to the effect that the parties weren't "in it for the

\footnotetext{
"Or at least those possibilities may exist in the perfect markets that are the subjects of economic models; for a skeptical view of the likelihood that arbitrage can do much to overcome the choices of "quasi-rational agents" in most actual markets, see Thaler, Quasi Rational Economics at 191 (cited in note 40).

${ }^{45}$ See Jolls, Sunstein, and Thaler, 50 Stan L Rev at 1486 (cited in note 20) (citing the possibility of arbitrage as one reason for the close relationship between spot market and futures prices). But see Thaler, Quasi Rational Economics at 191 (cited in note 40).
} 
money," or weren't "thinking of their rights in that way." While any attempt to explain these attitudes must therefore be somewhat speculative, I will suggest that they may be related in interesting ways to the absence of markets for the rights at stake in these cases. More specifically, the parties' attitudes may result from the lack of close substitutes for the rights involved in these cases; or it may be that putting the rights up for sale would have seemed to degrade the rights, or degrade the parties, in ways that would have made the parties uncomfortable. These two possibilities may in turn be related, and both may be connected-both as causes and as effects-to the absence of markets here.

a) Sources of distaste for bargaining: Problems of substitution and commensurability. There are not ready substitutes for the rights involved in nuisance cases. If I obtain an injunction requiring you to get rid of your barking dogs (or perhaps have them "de-barked"), and you offer me cash to dissolve the injunction, I cannot use the cash to buy peace and quiet to replace the peace and quiet I have sold away. Perhaps I could buy earplugs, or a loud stereo, or louder dogs of my own; but all of these solutions may well be quite inferior alternatives to being rid of the barking. If I could sell you my whole house, that would be a little different: then I could buy a different house, which, while not a perfect substitute, might at least be close. (Accordingly, mention of the possibility of buying a neighbor's whole house occasionally occurred before judgment in the cases considered here.) That there are no close substitutes for an entitlement does not make it either infinitely valuable or entirely incommensurable with cash, of course. Trade-offs between goods that are imperfectly commensurable are often made by individuals on their own out of necessity, as when Mr. Vore decided whether to keep, sell, or de-bark his dogs. But making such deals with others, explicitly and for cash, may make people uncomfortable for several reasons.

First, an absence of close substitutes makes it hard to put a price on an entitlement, and its holder may feel most comfortable erring on the side of caution and saying that it's "not for sale" (or in any event would be for sale only at some very high price). $\mathrm{He}$ thus minimizes the risk that he will feel regret once the unique good is lost. The agony of putting a price on a unique good is likely to be most severe when part of the reason for the good's uniqueness is that its owner is emotionally involved with it. Perhaps many people would be willing to forgo one of their hands for an extraordinarily large sum of money, but I would venture that few would want to figure out just how much they would demand to enter into such an arrangement, and that most people would 
find it dreadful to make the calculation if pressed. ${ }^{46}$ Nor do ordinary homeowners want to make a distressing determination of how much they would demand to put up with obnoxious odors in their home on a regular basis. So again, if a price were requested, the prospective seller might react to his unease by declining to name one, or by naming one so high that it seems unthinkable that it could be met (and so high that if somehow it were met, the seller would make the deal without any fear of remorse). ${ }^{47}$

Additionally, apart from the danger of regret, some parties may regard their rights in ways that make them poor candidates for a cash exchange. The act of putting rights up for sale requires a decision to think of them as commodities, which parties may resist. Compare two situations: one in which A offers B $\$ 5,000$ for B's family heirloom, and B declines, saying that it is not for sale and that he has no interest in bargaining over it; the other in which $A$ accidentally destroys the heirloom, and the two parties agree that $\$ 5,000$ is reasonable compensation for it. In the latter case the decision to "sell" the heirloom has been forced upon B; to accept cash in return for the heirloom requires no distasteful decision by $B$ to treat it as suitable for sale. Likewise, a dog owner might decline to order a $\$ 5,000$ medical operation on the animal that is certain to extend its life; yet if a doctor offers to buy the dog from the same owner for $\$ 5,000$ so that it can be gassed and made the subject of medical experiments, the owner might not entertain the offer at all. ${ }^{48}$ The point is just that even if people make trade-offs between poorly commensurable goods, that does not mean their valuation of those goods is stable or easily reduced to cash terms. It may not be possible to state any one price that the owner of an entitlement places on it; its value may depend on who is asking and why and on what sort of statement the parties would be making about the right-and about themselves-by entering into a cash transaction for it. ${ }^{49}$ These are instances of human complexity. Whether they are instances of irrationality in either a lay or economic sense is another and more difficult question. ${ }^{50}$

\footnotetext{
${ }^{46}$ See Sunstein, 96 Colum L Rev at 943-44 \& $\mathrm{n} 150$ (cited in note 38) (noting that individuals often may be reluctant or unwilling to calculate the monetary sum they would accept to allow an unpleasant event to take place).

${ }^{47}$ See Thaler, Quasi Rational Economics at 15-18 (cited in note 40).

${ }^{48}$ This example is based on a similar one used in Sunstein, 96 Colum L Rev at 943-44 (cited in note 38).

${ }^{19}$ See generally Elizabeth Anderson, Value in Ethics and Economics (Harvard 1995).

${ }^{50}$ In their discussion of economic rationality, Cooter and Ulen note that "behavior can be rational even though the ends are anti-social." Cooter and Ulen, Law and Economics at 11 (cited in note 12). But they also define rationality as requiring that the parties' prefer-
} 
The possible application of this principle to the nuisance cases considered here is that for the parties, the very act of entering into cash bargains with their enemies over their families' rights to comfort, or their right to carry on their livelihoods, might itself have entailed sacrifices. Thus the "price" that the holder would state in such a situation is not a price for the rights per se; rather, the "price" would reflect the cost of selling rights to a particular neighbor against the background of a particular history or context of beliefs and norms that makes cash bargaining for the right uncomfortable. The parties did not think of their rights as bargaining chips, and they did not particularly want to think about them that way. Their preferences and sense of value could have been be flattened onto an accountant's spreadsheet, Mercator fashion, but the process would have distorted them in a way that obliterated any bargaining range.

b) Sources of distaste for bargaining: Meanings of bribery. I want now to explore one particular source of the parties' distaste for bargaining that some of the lawyers mentioned: the aversion their clients would have felt toward the prospect of paying their adversaries not to do things they didn't want them to do. One of the lawyers referred to this as the prospect of a "bribe," which seems a fair enough characterization. The "best briber" has made frequent appearances in the literature of economic analysis, ${ }^{51}$ but not everyone is comfortable with the idea of paying bribes, even broadly defined. How often do we offer cash to other people to stop engaging in conduct that we do not like? ${ }^{52}$ Not often, at least not in this culture at this time.

To take a homely example, if I were sitting near a pair of loudmouthed patrons in a theater (a small-scale but potentially

ences be "stable" in the sense that they "must be transitive at any point in time, and they must not alter very quickly with the passage of time." Id at 234 \& n 8. Compare Richard A. Posner, Overcoming Law 16 (Harvard 1995) ("The individual imagined by economics is not committed to any narrow, selfish goal such as pecuniary wealth maximization. Nothing in economics prescribes an individual's goals. But whatever his goal or goals ... he is assumed to pursue them in forward-looking fashion by comparing the opportunities open to him at the moment when he must choose."); Jules L. Coleman, Efficiency, Exchange, and Auction: Philosophic Aspects of the Economic Approach to Law, 68 Cal L Rev 221, 225 (1980) ("Coase's theorem is not an empirical claim but is instead an analytic truth about what it means, under certain conditions, to act rationally.").

${ }^{51}$ See, for example, Guido Calabresi, The Costs of Accidents: A Legal and Economic Analysis 150-52 (Yale 1970); Posner, Economic Analysis of Law at 662 (cited in note 12) ("The settlement out of court of a tort or contract or private antitrust case is a form of perfectly lawful bribery, although the term is not used in these settings (except by economists!), because of its pejorative connotation.").

${ }^{52}$ By "conduct" I refer to primary conduct in the world-and thus would distinguish this problem from the payment of a settlement that stops a plaintiff from the "conduct" of bringing a lawsuit. 
acute nuisance), I might go to great lengths to quiet them. One thing I would not do, however, is offer them cash, even at the intermission when conventional transaction costs might be low. The reasons for my unwillingness to offer cash are difficult to pinpoint. No doubt an economist could identify possible sources of transaction costs latent in the situation (for example, some way in which strategic behavior or fear of it could create difficulties), but the problem seems to have more dimensions than that. As the lawyers in the nuisance cases sometimes noted, people do not like to pay for things that they do not think they should have to pay for. Perhaps the source of my unease is that paying the boors would imply a concession on my part that they are entitled to do what they are doing, and indeed that they are entitled to be paid to stop doing it. But there is still more to the resistance: an offer of cash would feel vaguely humiliating. It would be a hint of desperation, perhaps, or a minor form of groveling. Maybe the difficulty is that money, like law, is a substitute for violence, so that an offer of cash might seem a confession of impotence; or maybe it is that money is an instrument that people of means use to avoid the more unpleasant aspects of existence, so that an offer of cash to make a problem go away makes an awkward statement about class. Whatever the explanation, offering to pay for the quiet that seems rightfully mine would feel worse than enduring its loss. The transaction has a communicative component, and it is intolerable - or at least would be sufficiently distasteful to prevent any bargaining given the stakes involved. ${ }^{53}$ If I were competing

${ }^{53}$ In his discussion of Sturges $v$ Bridgman, 11 Ch D 852 (1879), a famous English nuisance case, Brian Simpson expressed his doubts about the likelihood of a bargain after judgment in related terms:

The reason why a market transaction in the sense of a purchase and sale of rights is usually not possible in such situations is that the parties are not willing to place their rights in the market. Once this is understood it becomes offensive not to respect this unwillingness. Life would indeed be quite intolerable if individuals did not in general respect social limits to the market-when invited to a dinner party it is unacceptable for a guest to make offers for the silverware or the wine or the pictures which adorn the dining room, or to attempt to sell life insurance to fellow guests.

A.W. Brian Simpson, Coase v. Pigou Reexamined, 25 J Legal Stud 53, 87 (1996). Elsewhere Simpson offers a similar analysis of another English nuisance case, Tipping $v$ St Helen's Smelting Co, 122 ER 588 (1863). There are, he suggests,

powerful social limits to the market, and those who offer money to resolve quarrels run a serious risk of aggravating the situation. The story of the negotiations between Tipping and his neighbour illustrates both points. Quarrelling neighbours and common lawyers, engaged in the process of dispute resolution at the margins of a largely traditional system of property law, inhabit one world, which is real and very untidy. Economists inhabit another world. Between them a gulf seems to be fixed. 
against the boors at an auction where the right to silence them were being sold, I might well outbid them, but that is another case (like the case of the accidentally destroyed heirloom) where others already would have done the work of conceptualizing the situation as one that will be resolved by paying cash.

A similar phenomenon may be part of the explanation for the parties' behavior after judgment in these nuisance cases. The parties may have been up against a set of manners and norms, both external and internal, that regulate the propriety of a cash exchange. They tended to have strongly held views about the righteousness of their positions, particularly about their right to enjoy their property as they saw fit. Offering thousands of dollars to their enemies to do what their enemies were supposed to do for free would have been hard on the parties' sense of themselves. It also might have been hard on the parties-and perhaps on their local reputations-to reveal themselves as being "in it for the money." Like most things, perhaps, those sensibilities have their price, but it was too high (relative to the stakes of the cases) to contemplate. As noted in the discussion of acrimony, the communicative component of a cash payment-here, the dash of humiliation that may accompany it, whatever the origins of such a reaction may be in this culture at this time-can go a long way toward preventing a bargain. ${ }^{54}$

These observations may help us understand the types of negotiations that occurred before judgment in the cases considered here. They tended to be of two kinds. First, there were adjustments made for "free" (in other words, without any exchange of money) to make the dispute go away (another form of compensation); an example is the reduced use of the lights on the baseball diamond in the Damitz case. And there were all-or-nothing offers to buy or sell the property at issue; the offers in Parker $v$ Ashford $d^{55}$ (one of the racetrack cases) are an example. There is an established market for entire pieces of property, so offering to buy a neighbor's house to resolve a dispute implies nothing novel or offensive, and occasionally is done. I did not find any cases where either side offered to pay or take money in return for a change in conduct or for an incremental adjustment of their rights. I believe

\footnotetext{
5 See Kelman, $52 \mathrm{~S} \mathrm{Cal} \mathrm{L} \mathrm{Rev} \mathrm{at} \mathrm{694-95} \mathrm{(cited} \mathrm{in} \mathrm{note} \mathrm{39);} \mathrm{Cass} \mathrm{R.} \mathrm{Sunstein,} \mathrm{Incom-}$ mensurability and Valuation in Law, 92 Mich L Rev 779 (1994). For some economic speculation about the reasons for the discomfort, see Eric A. Posner, The Strategic Basis of Principled Behavior: A Critique of the Incommensurability Thesis, $146 \mathrm{U} \mathrm{Pa} \mathrm{I} \mathrm{Rev} 1185$ (1998).

${ }^{55} 661$ S2d 213 (Ala 1995). For a discussion of the case, see text accompanying note 104.
} 
that those kinds of offers would have given some offense to prevailing norms about appropriate uses of cash.

c) The absence of markets as cause and effect of the distaste for bargaining. I have suggested a few possible reasons why bargaining for cash might have seemed inappropriate to the parties in these cases. If these ways of thinking about the parties' attitudes have merit, might they be understood as resulting from the absence of markets for the rights at issue? The answer was more straightforward when the obstacle under consideration was acrimony between the parties, because as a practical matter a robust market may allow parties to avoid each other. Here the answer is more complex, because markets have a number of features that might bear on the parties' attitudes toward bargaining. And the parties' attitudes toward bargaining may help explain the absence of markets, rather than the other way around.

I suggested that the parties' reluctance to bargain resulted in part from the lack of good substitutes for the rights involved in these cases. In a thick market that would not be a problemthough it is a bit difficult to visualize a thick market for the rights at stake here. First, we would have to imagine a situation in which parties on either side of a nuisance case are in competition with others to sell their rights. ${ }^{56}$ And then we would have to imagine good substitutes for the rights: a world where, as suggested earlier, the plaintiff's peace and quiet or the defendant's barking dogs are readily replaceable, or in which units of sentimental value and emotional attachment are experienced by the parties as fungible. Under those circumstances we would have truly thick markets for the rights in these cases, which might indeed have made bargaining after judgment more likely. But to imagine such a state of affairs is not just to imagine some logistical changes that would make bargaining more efficacious. It is to imagine the goods at stake altered in fundamental ways.

Or perhaps it is to imagine the parties themselves altered in fundamental ways. To say there are no substitutes for a good is to make a statement about the way people feel about the good, not

\footnotetext{
${ }^{56}$ One might imagine a situation where each member of a large group of plaintiffs has the right to completely release the nuisance-creating defendant from an injunction that a court has issued, so that the members of the plaintiffs' group would bid each other down to their reservation prices. Or to reverse the situation, one might imagine a large group of defendants; all of them are necessary partners in creating a nuisance (but the courts have given the defendants the right to continue their activities). If the plaintiff can buy out just one of the defendants, the nuisance will end. So each of the partners in the creation of the nuisance lowers its price; each competes with the others until their reservation prices are smoked out, as it were.
} 
about the good itself. People decide whether they think that goods have substitutes. If Vore had thought that one place for raising his dogs was as good as the next, or if he had felt ready to substitute freely between dogs and cats, there would have been no substitution problem in Tichenor $v$ Vore; if Damitz had felt that other uses of his land were just as satisfactory as using it as a baseball diamond, there would have been no substitution problem in $B A G K O v$ Damitz. No doubt there are many cases where parties do feel roughly that way about their rights. For those parties, compromises are easy enough to make; the goods involvedwhich may, from an objective standpoint, look similar to the goods at stake in the cases recounted here-do have substitutes, so far as their owners are concerned. The cases considered in this Article, however, are precisely those in which the parties doubted that, so far as they were concerned, there were satisfactory substitutes for the entitlements at issue. The absence of markets, in the sense of plentiful chances to make substitutions, thus may not be the most powerful way of explaining the lack of bargaining after judgment in the cases considered here. Since substitutability is a subjective conclusion, rather than an inherent property of entitlements, that explanation would just amount to saying that the parties would have bargained after judgment if they had felt differently about their rights. One could as well reverse the propositions and say that if the parties had felt differently about their rights, there would have been plenty of substitutes for them-and, in effect, thick markets.

It would risk a similar tautology to say that robust markets would have removed the other reasons I have suggested for the parties' reluctance to bargain: their discomfort toward the prospect of treating their entitlements as commodities, or toward the prospect of bribing their adversaries. No doubt those impediments to bargaining would have dissolved if the parties were operating in a well-functioning market, rather than being forced to deal only with each other. Markets consist in part of signals indicating when and where and what it is appropriate to exchange; they grease the cognitive skids that enable people to make substitutions between what they own and dollars, and between dollars and what they want. Markets also consist in part of norms that make the purchase and sale of entitlements seem ordinary. They strip bargaining of its communicative aspect, and in particular of the malodorous social meaning that may attach to suggestions outside of a market that someone pay their neighbor to behave better. So if the parties had been operating in robust markets, they might well have felt differently about bargaining. But the 
point here resembles the one made a moment ago: where an offer of cash would entail a loss of face, to say that this would not be a problem if there were a robust market amounts to little more than saying there would have been no obstacle to bargaining if the parties had felt differently about their rights or about bargaining. Likewise, to say that norms disfavoring certain types of cash offers would have presented no difficulties if markets had been well-functioning may be little more than a truism, akin to saying just that norms would not have been obstacles if they had been different. ${ }^{57}$

To sum up, thin markets are a familiar way to explain failures of bargaining when the reason for the failures is strategic behavior by the parties. Competitive markets tend to make strategic behavior untenable; it is hard for a party to bluff if others are competing to make more attractive bids. But when, as in these cases, the impediment to bargaining is that the parties do not want to bargain-because they detest each other, because they are laboring under various norms about appropriate exchanges of cash, or because they have attitudes toward their rights that make them awkward subjects for cash exchangesthen blaming the lack of bargaining on the absence of thick markets is more problematic; it may be just as accurate to blame the absence of markets on the parties' attitudes toward their rights and their norms about bargaining.

The existence of these attitudes and norms creates a vulnerability for economic models that predict bargaining in settings where markets are not established-models that effectively treat low transaction costs as synonymous with robust markets, without considering the possibility that robust markets consist not just of circumstances that make cash exchanges easy but also of norms and beliefs that make it comfortable to treat rights as commodities. This discrepancy between the market-like norms about bargaining that economists imagine and the other norms that lawyers may encounter even when transaction costs are low might be behind the odd suggestion, made by one of the plaintiff's lawyers in Payne $v$ Skaar, that "[i]f Easterbrook ran the feedlot and Posner were the neighbor, we might have been able to negotiate something," 58 but that the "frame of reference of these peo-

\footnotetext{
${ }^{57}$ Maybe the "if only there were a thick market" counterfactual can be given a little more substance by focusing on the competition that markets imply, and the ways in which the existence of competition may change norms: the parties to these cases might have felt. differently if they were surrounded by lots of other bidders; the other bidders not only would create competition but would make bargaining seem "normal" and not dishonorable.

The maker of this improbable prediction was a graduate of the Northwestern Uni-
} 
ple" was different. At first this sounds like a mistake on the order of supposing that a Freudian is someone who acts as Freudian theory would predict. But the attorney was gesturing toward a more reasonable point: translating entitlements into opportunities for pecuniary improvement does not come naturally or comfortably to everyone. Daniel Farber has noted that "[i]f the idea that victims bribe polluters is startling, people are not likely to think of it themselves; if they do not think of it themselves, they are not likely to do it. If only a brilliant person can think of doing something, it is unlikely that most people will adopt that course of conduct." ${ }^{25}$ You don't have to be brilliant to behave as an economist would predict; but to see a court's judgment as the starting point for a round of negotiations rather than as the final chapter in a dispute, it may help to have had some practice thinking that way or some cues from elsewhere in the environment that make such possibilities seem available and not dishonorable ${ }^{60}$ Economists habitually see those possibilities. For those less quick to see them or slower to warm to them, there are markets: sets of norms that make it seem natural and untroubling to trade cash for rights. Outside of markets, for one ordinary individual to pay another not to do something seems distasteful-or so I hypothesize. This is an area ripe for further research. The economics of nonmarket behavior have been studied, ${ }^{61}$ but the nature and extent of people's willingness to exchange cash for various kinds of rights and behaviors outside of markets have not received comparable attention.

\section{Transaction Costs}

One possible reaction to the behavior described here is that it only shows how high transaction costs are even in simple nuisance cases. But are the obstacles to bargaining in these casesthe parties' bad blood and their distaste for bargaining-properly thought of as transaction costs? ${ }^{62}$ What stance should the law

versity School of Law.

${ }^{59}$ Daniel A. Farber, The Case Against Brilliance, 70 Minn L Rev 917, 919-20 (1986).

${ }^{60}$ Compare Robert H. Frank, Thomas Gilovich, and Dennis T. Regan, Does Studying Economics Inhibit Cooperation?, $7 \mathrm{~J}$ Econ Perspectives 159 (Spring 1993) (suggesting that economics students are more likely to engage in strategic behavior than noneconomists). 1976).

${ }^{61}$ See generally Gary S. Becker, The Economic Approach to Human Behavior (Chicago

${ }_{62}$ This question was anticipated in part in Mark Kelman, Comment on Hoffman and Spitzer's Experimental Law and Economics, 85 Colum L Rev 1037, 1038-39 (1985) (suggesting that "Coase Theorem advocates underestimate two phenomena that resemble, but would not be helpfully thought of as, transaction costs": first, "any subjective aversion to valuation or monetization of internal desires" and, second, "any aversion to the social 
take toward acrimony between parties, or toward norms and attitudes that make them reluctant to bargain? The question is of particular interest because it may bear on the relationship between the cases described here and the Coase theorem. Suppose we regard enmity and a distaste for treating rights as commodities as transaction costs. Transaction costs in these nuisance cases would then seem quite high, and in such circumstances the Coase theorem would predict that the courts' judgments would determine the final resting place of the rights-as seems to have happened. But if those obstacles to bargaining are not considered transaction costs, then perhaps the cases considered here are not consistent with the Coase theorem after all: the courts' assignments of rights were final, and if the lawyers are believed, this would have been true no matter what the court had done-for reasons that cannot be considered transaction costs. These conclusions would depend, of course, on which of the many available definitions of the Coase theorem one is using, and this Article is not the place to canvass those possibilities. The point for now is only that the decision to classify certain obstacles to bargaining as transaction costs has important implications from both a practical and theoretical standpoint. All of these are rich questions that deserve a fuller treatment than can be given here, but a few preliminary observations can be made about them.

The notion of "transaction costs" sometimes is used imprecisely, but generally it denotes either logistical obstacles or problems of strategic behavior that make it hard for parties to effectuate their consent to a bargain that would make them both better off. ${ }^{63}$ Whether a party is "better off" is measured, on this view, by the party's own lights. That is why economic analysts prefer to leave the allocation of rights to voluntary transactions wherever they are feasible: a voluntary transaction requires the consent of both sides, and their consent is proof that both sides consider themselves better off as a result. In a case where transaction costs are prohibitive, however, there may be a price at which both sides would indeed want to make a trade, but they cannot discover the price and effectuate their consent because of coordination problems or strategic behavior by either side. Unrealized gains from trade-and thus inefficiency-are the result. ${ }^{64}$

This notion of transaction costs has many applications. The application of interest here is the one that bears on the selection

practice of bargaining or monetization of disputes-a reluctance to believe it is appropriate to deal with friction between people on all occasions by explicit transfers").

${ }^{\infty}$ See, for example, Cooter and Ulen, Law and Economics at 100-02 (cited in note 12).

${ }^{6}$ See Calabresi and Melamed, 85 Harv L Rev at 1106-07 (cited in note 2). 
of property rights and liability rules as remedies: the idea that when transaction costs are high, the law should compensate by placing rights where they would end up if transaction costs were low-in other words, in the hands of whichever party would pay the most for them. In this way the court makes both sides better off by making the deal that they would make for themselves if they could. Interesting difficulties arise, however, if we try to use this model to make sense of the obstacles to bargaining the parties encountered in the cases considered here. The difficulty in these cases was not that the parties had trouble effectuating their consent; rather, there was no consent to effectuate. The problems the lawyers described arose from the content of the parties' preferences-their opinions about one another or about bargaining. Those difficulties, by themselves, would seem to provide no basis for an award of damages on efficiency grounds; a court could not, by awarding damages, have made the deal for the parties that they would have made for themselves if they could, because they did not want to make a deal. The impediments to bargaining recounted by the lawyers here were not transaction costs by conventional definitions of that term.

Now those obstacles to bargaining - the parties' acrimony and their attitudes toward bargaining-nonetheless could be treated as transaction costs by the law. A pragmatic definition of "transaction costs"-one based on the consequences of the term for judicial purposes-is that they are impediments to bargaining that should be regarded as bad, as "noise," as problems that courts should help the parties overcome by putting the rights into the hands of the party who would end up with them if only the impediments weren't in the way. But which impediments to bargaining are the bad kind? The answer to this question requires a normative judgment from outside economics. For example, if an economist suggests that a court should use damages as a remedy when the parties to a lawsuit are too numerous for bargaining after judgment to be feasible, the implicit belief behind the suggestion is that the parties' numerosity is interfering unhappily with the expression of some baseline state of affairs-a world where parties can bargain easily if that is what they want. But if one prefers a different baseline, one can generate a different theory of transaction costs. ${ }^{65}$ If our baseline were a world where people have no racial biases, then racial biases in effect would become

\footnotetext{
${ }^{65}$ For similar treatment of transaction costs as presenting a baseline problem, see Jack M. Beermann and Joseph William Singer, Baseline Questions in Legal Reasoning: The Example of Property in Jobs, 23 Ga L Rev 911, 956-61, 968-72 (1989).
} 
transaction costs: unfortunate impediments to bargains that otherwise would maximize the parties' utility (or at least the sort of utility the law is prepared to recognize). Racism would be an instance of the dysfunction that it is part of the law's purpose to help overcome.

Alternatively, if our baseline were a world not merely where parties can bargain if they want to but where they want to bargain wherever there is a pecuniary advantage to be had from doing so, then their preferences for things other than cash would in effect be treated as transaction costs. ${ }^{66}$ That is approximately the approach required if acrimony and a distaste for bargaining are to be regarded as transaction costs. The idea would be that one of the parties really does value the rights more than the other, in the sense that the party would have been willing to bid the most for the rights if they were the subject of an auction. The important thing is to get the rights into the hands of that party. The fact that neither party would want to make a deal with the other is beside the point; that aspect of the parties' preferences is noise that prevents us from hearing the music of their true utility schedules. On this view, then, law might be understood as a way of reshaping the world to look the way it would not only if conditions were different, but if people were different-if they had better preferences, if they got along better, if norms were different. Here the better preferences would be not those that flourish merely when transaction costs are low, but rather those that flourish when markets are strong-preferences that perhaps can be shorthanded as the sort that corporations often are thought to have: a willingness to bargain unencumbered by acrimony, emotion, and a gut distaste for trading rights for cash in some contexts. I am not aware of any explicit champions of this view, but it may have its inadvertent advocates.

The description just sketched treats the economic approach to law as just one of a family of approaches that view law as an instrument for making the world look the way it would without certain regrettable features: a theory about what should be counted by the law, and about what the law ought to help us

\footnotetext{
${ }^{66}$ The relationship between these approaches was striking in one of the cases considered here (which I shall not identify). The lawyer for one of the parties said that the other party was thought to be gay, and perhaps to have AIDS. Given the cultural context the lawyer described, this stigma would have made bargaining between the parties impossible to imagine. If a court thought this stigma was offensive to public policy, and that it was the obstacle to bargaining after judgment (in the actual case, it was far from being the only reason), there would be a strong argument for treating the stigma as a transaction cost and awarding damages.
} 
overcome. In principle, the features the economist regrets and wants to use the law to overcome usually are practical impediments to bargaining-transaction costs in the conventional sense. In practice, if economists assume that people are interested in bargaining to maximize the pecuniary payoff of a situation, they are making an unspoken additional move toward the corporate baseline-in other words, toward the use of economics to give the world the shape it would have not only if conditions were different but if people were different than sometimes they are. There may be nothing wrong with such a move; in some instances it may describe the world well, in which case it can be defended with an appeal to the parties' consent (and has all the strengths and weaknesses to which that defense is prone), whether the consent is actual or hypothetical-but-plausible. But in situations where people are not like that-situations where there appears to be no consent to bargaining regardless of which way the court assigns the rights-the decision to imagine them with corporate preferences requires a different defense. The usual justification of the economist's view of transaction costs, which is that courts should minimize or compensate for them because they are obstructing the parties' ability to make a deal, no longer is available. By assumption the parties do not want to make a deal; the question is whether the reasons for this ought to be regarded-or rather condemned-as transaction costs. The question might possibly be recast as whether people's departures from economic rationality ought to be treated as transaction costs. "Might possibly" because, as noted earlier, it is not necessarily clear whether the parties to these cases were behaving irrationally in either an economic or more conventional sense. ${ }^{67}$ "Ought to be treated" because deciding whether such departures are transaction costs involves a normative decision about how the law should regard certain types of attitudes and behaviors, not a semantic or even a strictly positive decision about the meaning of the words "transaction costs."

\section{Particularism}

As noted at the outset of this Article, nuisance cases have taken on an expository significance that probably outruns most analysts' actual interest in them. They are used as examples to illustrate theories that are intended to have broad applicability. That is their purpose in Coase's paper: Coase was using the cases

\footnotetext{
${ }^{67}$ See note 50.
} 
not because he particularly cared about nuisance law, but to illustrate larger points about regulation and the consequences of allocating rights in various ways. Others likewise have used nuisance cases as parables to illustrate their general views of when courts should use property rights and liability rules as remedies. So maybe it is of minor concern whether there are discrepancies between what economists say will happen after nuisance cases are over and what actually does happen. An alternative possibility, however, is that the poverty of the example has ominous implications for the enterprise it is intended to serve. Here the enterprise is the creation of economic models applicable to a broad range of legal problems. It is common for economic analysts of remedies to theorize at a high level of generality, applying the same model to diverse areas of law-to property and accident law, for example, or to either of these areas and the law of intellectual property. ${ }^{68}$ The power to generalize so aggressively is said to be one of the attractive benefits offered by economic analysis. ${ }^{69}$ I suspect, however, that the economic analysis of remedies will not become useful to courts and lawyers until scholars approach the analytical project with greater particularity.

More particularity in the economic analysis of remedies may show that some kinds of cases are more likely than others to result in bargaining after judgment. Certainly I do not mean to argue that nuisance cases are typical; they may well lie at the far end of the spectrum of decisions subject to renegotiation by the parties after a case is over-the end of the spectrum where such bargaining is least likely. But we know little about the spectrum's character. At the opposite end from nuisance cases may lie, for example, trademark cases involving corporations; it seems plausible to guess that substantial corporations behave differently than individuals-that on account of their duty to maximize the value of the corporation to shareholders (among other reasons), corporate officers may be less affected by the difficulties encountered in the cases this Article considers. But perhaps those disputes have their own sociology: their own unique pathologies or

${ }^{6}$ See, for example, Ayres and Talley, 104 Yale L J at 1092-97 (cited in note 3); Hoffman and Spitzer, $15 \mathrm{~J}$ Legal Stud at 163-70 (cited in note 4); Hoffman and Spitzer, 71 Wash U L Q at 104-06 (cited in note 39); Kaplow and Shavell, 109 Harv L Rev at 748-57 (cited in note 3). There are many instances, of course, where the applications of the Coase theorem are more sensitive to the details of the context (though not necessarily the behavioral context). For applications to real and intellectual property, respectively, see, for example, Robert P. Merges, Of Property Rules, Coase, and Intellectual Property, 94 Colum L Rev 2655 (1994); Stewart E. Sterk, Neighbors in American Land Law, 87 Colum L Rev 55, 85-88 (1987).

${ }^{69}$ Posner, Economic Analysis of Law at 18, 272-73 (cited in note 12). 
other features that give bargaining after judgment (or beforehand) its shape and make it either straightforward or problematic. In all events, corporate trademark cases do not arise in the same setting as nuisance cases; they do not involve one neighbor's invasion of another's territory by conduct of an activity obnoxious to the senses, and thus they may not provoke the same feelings and reactions or activate the same norms. They probably require a separate analysis.

Greater particularity may also show that the source of a right can affect how readily it is traded after its initial assignment. ${ }^{70}$ One of the broader ideas in Coase's paper is that where the legal system assigns rights and where the rights ultimately wind up are different questions that may have little to do with each other when transaction costs are low. ${ }^{71}$ But it may not be useful for practical purposes to speak so broadly of "the legal system" as the source of people's rights. Some of Coase's examples, such as the nuisance cases, involve entitlements created by courts. But his examples of liability for cattle trespassing onto crops do not imply any particular source for the entitlements except the government in a general sense; the rights may be created by legislation. ${ }^{72}$ Subsequent writers have suggested that Coase's point applies to entitlements created in any number of other ways. $^{73}$ Like writers who skip between different areas of law, these writers skip between different ways that entitlements come into being. Today a court (but it could have been a legislature or an agency or a king) assigns an entitlement, and now the world is the same as it was yesterday except with a different set of rights for the parties to use as points of departure in their negotiations. The important question is just whether there are practical impediments to their bargaining. But the manner in which entitlements are created may well affect how readily they are exchanged. If a system assigns rights by inviting the parties to brawl for them, we might think twice before expecting to see much negotiation between the parties after the brawling is over; the litigation process can affect people's preferences, causing them to think differently about each other and about their rights.

\footnotetext{
${ }^{70}$ Compare George Loewenstein and Samuel Issacharoff, Source Dependence in the Valuation of Objects, $7 \mathrm{~J}$ Behav Decision Making 157 (1994).

${ }^{7}$ See Coase, 3 J L \& Econ at 5-6, 10 (cited in note 1).

${ }^{72}$ As is the case in Shasta County. See Ellickson, Order Without Law at 42-48 (cited in note 4).

${ }^{73}$ See, for example, the passage from Hoffman and Spitzer, $15 \mathrm{~J}$ Legal Stud at 151, 160 (cited in note 4), accompanying note 18. See also Polinsky, An Introduction to Law and Economics (cited in note 13) (applying the Coase theorem to property, contract, and tort disputes).
} 
The nuisance cases considered here are examples. When one neighbor sues another, the stakes of their dispute change. Their rights are going to be settled in an adversarial process where one side will be vindicated and the other will be made a loser. Litigation to judgment, especially when combined with the other contextual considerations this Article has discussed, thus may be likely to exacerbate ill will and foul the environment for bargaining afterwards. And framing the issue in the suit as a question of who has the rights may make it less likely that either side will be interested in translating their interests into a cash offer or demand: they never thought of themselves as being in it for the money, and they don't want to be regarded that way by others. Whether there is any better way to resolve nuisance cases is an interesting question $;^{74}$ the more general point, however, is that we need not necessarily expect the same outcomes in contexts where rights are assigned by legislative means that keep the flame lower.

The same need for particularity may apply, finally, to critiques of economic analysis. If economic models have weaknesses, then of course the important thing is to speak concretely about what they fail to capture, and where. Again, I would hypothesize-cautiously, in view of the lack of data on the subject-that the prickly preferences held by the parties to the cases considered in this Article may be a more prominent feature of individuals' behavior than of the behavior of substantial corporations, ${ }^{75}$ and there may be other important distinctions of that sort to draw. Are the norms and attitudes that may confound conventional economic models the same in property disputes as in contract disputes? Once parties have gotten themselves into a contractual relationship and are trading entitlements for cash, perhaps the "commodification ice" is broken and the obstacles to bargaining after judgment found here fall away. Where businesses are involved, does the type of corporation involved, or the industry context in which it operates, make a difference? It may be dispiriting to suppose that we need separate theories about behavior by corporations and by individuals, about behavior in property disputes and in contract disputes, or about behavior before judgment and

\footnotetext{
${ }^{76}$ On which see Robert C. Ellickson, Alternatives to Zoning: Covenants, Nuisance Rules, and Fines as Land Use Controls, 40 U Chi L Rev 681, 762-68 (1973).

${ }^{75}$ Hoffman and Spitzer make this suggestion with respect to the endowment effect. See 71 Wash U L Q at 109-11 (cited in note 39). See also Thomas F. Cotter, Pragmatism, Economics, and the Droit Moral, 76 NC L Rev 1, 61-62 (1997). But see Thaler, Quasi Rational Economics at 185 (cited in note 40) (suggesting that the endowment effect may apply to firms as well as individuals).
} 
after judgment, and about behavior inside litigation and outside litigation. But I suggest that we may well need all of those theories, and more, if we want to make usefully reliable statements about how real parties are likely to behave under any of those circumstances.

\section{LIMTTATIONS AND OBJECTIONS}

I now consider some objections to the methods used in this study and some limits on the conclusions that can be drawn from it.

\section{A. Cases Litigated to Judgment}

This study might be said to suffer from a sampling bias: it only considers cases that were litigated to final judgment. What about the cases that settle? This is an important point, though when framed as a sampling bias it reflects a misunderstanding of the study and its conclusions. I am not purporting to ask or answer any questions about what happens in cases that settle, so excluding them is just a limitation on what the study means. Cases litigated to judgment are, of course, only the tip of an iceberg consisting of all nuisance disputes, most of which are resolved without lawyers; some large proportion of the rest surely are settled without filing suit, or without a trial, or without an appeal. The tip probably is not representative of the berg: cases where a court enters judgment may be the ones least likely ever to involve bargaining between the parties; people who require a court to resolve their problems with their neighbors may well tend to be the ones most stubborn or hostile to the idea of bargaining over the rights involved in the first place (indeed, the lawyers occasionally described their clients as outliers in just this way). So notwithstanding the references in the literature to postjudgment bargaining in nuisance cases, ${ }^{76}$ it should not be terribly

${ }^{76}$ See, for example, Cooter and Ulen, Law and Economics at 175-76 (cited in note 12) (analyzing the Boomer case, where the court ordered a cement factory to compensate the plaintiffs for the nuisance or face an injunction, in light of the parties' incentives to bargain after judgment); Coursey, Hoffman, and Spitzer, $16 \mathrm{~J}$ Legal Stud at 235-36, 244 (cited in note 4) (in small nuisance cases, "a court should choose legal remedies by presuming that the parties can and will bargain efficiently," and in general "courts should choose legal rights and remedies in many situations under a presumption that parties can and will exhaust all gains from trade"); Krier and Schwab, 70 NYU L Rev at 453 n 46, 455 (cited in note 3) (repeatedly discussing "post-judgment bargaining"); Polinsky, 32 Stan L Rev at 1092-1109 (cited in note 14) (generally discussing various factors that influence the likelihood of bargaining after judgment); Posner, Economic Analysis of Law at 80-81 (cited in note 12) (analyzing the Boomer case in terms of the parties' likely behavior after judgment). 
surprising that in cases that make it to final judgment-to the bitter end, so to speak-the parties often will not be interested in trying to bargain afterwards.

Perhaps discussions of nuisance remedies therefore ought to be reoriented away from the analysis of bargaining after judgment by the parties, and should be focused instead on ways that a court's decisions affect settlement negotiations by parties who come later. That is a promising idea, but such a move should be made cautiously. First, we do not know anything about settlement patterns in nuisance cases. We know some things about the rates of settlement in civil litigation generally, ${ }^{77}$ but nothing about whether nuisance cases, once they enter the court system, settle as often as other kinds of cases do-as often as, say, auto accident cases. Nuisance cases differ from most other tort cases in a potentially important respect: in a typical tort suit the damage has been done, leaving the plaintiff with nothing to do but seek money; since the amount of money that will change hands is the only question in the case, some of the obstacles to bargaining discussed in this Article will not arise. The reluctance to enter into a transaction is not at issue. A transaction has been forced, and the stage is set for bargaining over a dollar amount. That is not true in a nuisance case. The plaintiff has hope of winning an injunction and avoiding a forced transaction altogether. This may result in fewer cash bargains in nuisance suits than we see elsewhere, since parties disinclined to trade their rights for cash are not obliged to do so.

And in nuisance cases that are compromised, we know little about the character of the bargaining and adjustments involved, or about what influences those arrangements and to what degrees. ${ }^{78}$ Do the compromises involve exchanges of cash, or do they involve noncash bargaining in the form of other adjustments the parties can make (including unilateral adjustments by the defendant just to be rid of the lawsuit)? When parties do hammer out a compromise, how closely are they trying to predict what a court would do if the case were litigated to judgment? Professor Ellickson has suggested that nuisance-type disputes between neighbors often will be settled according to local norms without much refer-

"See Marc Galanter and Mia Cahill, "Most Cases Settle": Judicial Promotion and Regulation of Settlements, 46 Stan L Rev 1339 (1994).

${ }^{78}$ For an interesting general discussion of settlement negotiation, see Samuel R. Gross and Kent D. Syverud, Getting To No: A Study of Settlement Negotiations and the Selection of Cases for Trial, 90 Mich L Rev 319 (1991). See also Robert Cooter and Stephen Marks with Robert Mnookin, Bargaining in the Shadow of the Law: A Testable Model of Strategic Behavior, 11 J Legal Stud 225 (1982). 
ence to law, ${ }^{79}$ and this no doubt is correct; those norms also may figure prominently in the cases that settle after they fall into the hands of lawyers, whose primary goal will be to come up with some arrangement that both sides consider bearable. I am not suggesting, of course, that nuisance cases never settle, or that they never settle for cash, or that a court's decisions do not influence later settlements. I only am pointing out that we have little information about these questions, and that their details may bear critically on the reliability of predictive models. It is easy enough to create assumptions about all of these matters, but then it also has been easy enough to make assumptions about how parties to nuisance cases that go to judgment behave afterwards.

\section{B. Appealed Cases}

There is another form of possible sampling bias in this study, and this time the term potentially is apt: the study only includes cases that generated opinions published on Westlaw or Lexis, which usually meant cases that generated an appeal. It is possible that appealed cases tend to involve parties more stubborn than those who accept the trial court's judgment without appealing; maybe the latter parties make the kinds of trades not made by the parties in the cases I studied. ${ }^{80}$ While I doubt this is a strong source of bias (I doubt, in other words, that the difficulties described by the attorneys in these cases are much less formidable in cases litigated to judgment but where no appeal is taken), I cannot rule it out and therefore flag it for the reader.

\section{The Courts Are Even Better Than We Thought}

Another possible reading of the results of this study is that it only shows courts are doing a perfect job by economic lights: they are always assigning rights to the parties that value them the most, thus obviating the need for any bargaining. (Or at least courts are only using property rights to protect entitlements in cases where the assignment of the entitlement seems efficient.) It is important to tread carefully here, because there are many possible definitions of efficiency and they can cause confusion. ${ }^{81}$ For

${ }^{79}$ Ellickson, Order without Law at 270-75 (cited in note 4).

${ }^{60}$ There is some discussion of this issue in Richard A. Posner, Rational Choice, Behavioral Economics, and the Law, 50 Stan L Rev 1551, 1571-72 (1998), and in Christine Jolls, Cass R. Sunstein, and Richard Thaler, Theories and Tropes: A Reply to Posner and Kelman, 50 Stan L Rev 1593, 1603-04 (1998).

${ }^{81}$ See Lewis A. Kornhauser, A Guide to the Perplexed Claims of Efficiency in the Law, 8 Hofstra L Rev 591 (1980) (arguing that the various definitions of efficiency raise questions about the apparent simplicity of economic theories of law); Jules L. Coleman, Effi- 
example, one way to define efficiency is to say that an assignment of rights is inefficient if it results in unexhausted gains from trade. ${ }^{82}$ Given that definition, I agree that courts routinely make efficient assignments of rights in these cases: there will be no unexhausted gains from trade no matter which way the court assigns the rights; regardless of who wins and loses, the price the winner will demand to relinquish the rights usually will be more than the price the loser is willing to pay. If the cases are understood in this way, a court concerned about efficiency can relax. Anything it does will be efficient, at least so far as the case at hand is concerned; nothing it does will result in unrealized gains from trade for the parties. Perhaps that is the best way to understand these results. In order to be at odds with what I am saying, by contrast, the criticism must be a claim that of the two general ways a court can assign rights, one will be efficient and the other will not be; that the courts in these cases assigned the rights efficiently; and that if the courts here had not done so, the parties would have bargained after judgment, or at least that bargaining would not have been foreclosed by the obstacles described in this Article. If this interpretation is correct, then the absence of bargaining would show only that courts are skillful in awarding property rights to whichever party would pay the most for them. ("The courts are even better than we thought," the economist might say.)

I do not think the account just presented is a good description of how courts decide nuisance cases, but it will not be fruitful to debate here whether judges try to award the rights in nuisance cases to the party that would pay the most for them. For even if it could be shown that courts do not make such assignments deliberately, one still could argue that courts sometimes do it inadvertently, and since we cannot know for sure when courts are doing so, we cannot know whether and when the parties' failure to bargain after judgment has any significance. But the suggestion of this Article is not that parties fail to bargain regardless of whether the courts assign the rights efficiently or inefficiently. Rather, the suggestion is that this way of thinking about the assignment of rights-as "efficient or inefficient" in some helpful sense-in fact is unhelpful here because "the party that would have paid the most for the rights" is not as stable a concept as economic models assume it to be. The parties' valuations depend

ciency, Utility, and Wealth Maximization, 8 Hofstra L Rev 509, 512-20 (1980) (offering four different conceptions of efficiency).

${ }^{82}$ See, for example, Hoffman and Spitzer, $15 \mathrm{~J}$ Legal Stud at 150 (cited in note 4). 
on the context in which they are asked for them (when, and by whom, and for what purpose), and on which party was assigned the rights in the first place.

Put differently, the criticism I describe would reflect a disagreement with (or disbelief of) what the lawyers said about their cases. The lawyers said that the obstacles to bargaining that they described would have foreclosed the possibility of negotiations even if the rights had been assigned the other way. The critic I anticipate would say the lawyers are mistaken or are trying to give accounts of their cases that make themselves or their clients look good; there would have been bargaining between their clients if the cases had been decided the other way. While conventional transaction costs might have frustrated the process, the critic would say, there at least would have been a will to bargain; statements to the contrary by lawyers are just talk. I consider this argument less plausible than the competing hypothesisthat the lawyers accurately perceived and described their clients' likely behavior. The dynamics of the cases here are foreign to economic models, but are they foreign to human experience? If two parties detest each other and would find a cash exchange somewhat bizarre or offensive under the circumstances, it seems reasonable to suppose that those considerations would make bargaining after judgment unlikely regardless of what the court does. This would be obvious if the cases involved requests for injunctions against protests outside abortion clinics: one would not expect bargaining around the court's judgment, both because of the parties' likely feelings toward each other and because of their attitudes toward the rights at stake. Feuding neighbors are capable of developing broadly comparable attitudes. Or so their lawyers say; but then what evidence is on the other side, militating against the lawyers' accounts?

\section{Conventional Transaction Costs}

Another possible argument is that the real obstacles to bargaining in these cases were conventional transaction costs: the bilateral monopolies ${ }^{83}$ freeloader and hold-out problems, ${ }^{84}$ and private information ${ }^{85}$ that have been much discussed in the litera-

\footnotetext{
See generally Landes and Posner, The Economic Structure of Tort Law at 45 (cited in note 12); Posner, Economic Analysis of Law at 68-70, 81 (cited in note 12).

see generally Calabresi and Melamed, 85 Harv L Rev at 1107-10, 1116-20 (cited in note 2); Posner, Economic Analysis of Law at 69 (cited in note 12).

${ }^{85}$ See Ayres and Talley, 104 Yale L J at 1027 (cited in note 3) (arguing that divided entitlements can facilitate trade by inducing claim holders to reveal information); Joseph Farrell, Information and the Coase Theorem, $1 \mathrm{~J}$ Econ Perspectives 113, 117-21 (1987).
} 
ture. The conventional transaction costs just enumerated essentially are varieties of strategic behavior that tend to frustrate attempts at bargaining. They do not seem prominent in these cases, and were not the types of problems the lawyers described. Here there were no attempts to bargain, and the lawyers generally did not mention strategic behavior (or fear of it) as an impediment to making a deal. ${ }^{86}$

It is possible, of course, that if the obstacles to bargaining the lawyers described had not been present, problems of strategic behavior would have come to the fore. In most of the cases it appeared that if the parties wanted to make a deal it would not have been difficult, but there were some cases where conventional transaction costs loomed over the horizon. In Sharp v 251st Landfill, Inc ${ }^{87}$ for example-a case where residents won an injunction against the creation of a landfill in their neighborhood-the landfill company might have been reluctant to try buying the rights from the plaintiffs, since there might have remained a danger that other neighbors would emerge later to complain about potential contamination of their water supply. They could have been approached directly, but it might have been hard to obtain everyone's agreement; some of residents might have held out. As it happens, however, the negotiations appear to have been doomed before those difficulties were encountered. The lawyers reported that the parties were not interested in trying to make a deal, and that this lack of interest was not related to coordination problems. (In cases where there were no such potential coordination problems, there still was no bargaining, and for the same stated reasons.)

A determined economist, of course, might nevertheless insist that those potential transaction costs-eventual difficulties the parties might have faced in enforcing whatever deal they made, for example-were the true reasons for the absence of bargaining in these cases. Even if the lawyers were speaking in earnest, their accounts were just unconscious attempts to dress up humdrum practical problems of strategic behavior in the language of principle and high drama. The difficulty with this analysis, as with any theory of false consciousness, is that it is hard to falsify. If the parties would not have bargained no matter how the rights

${ }^{86}$ An exception is 44 Plaza, Inc $v$ Gray-Pac Land Co, 845 SW2d 576, 577 (Mo App 1992) (discussed in text accompanying notes 112-13), involving the fireworks dealers: each had a concern that the other could not be trusted to carry out promises. But that fear seems not to have been the "but for" cause of the lack of bargaining; this was a case where one of the parties tried to strangle the other.

${ }^{87} 925$ P2d 546 (Okla 1996) (discussed at text accompanying notes 102-03). 
were allocated, then it was-perforce-a case of high transaction costs, whether they realized it or not. This account does not seem to me to be persuasive or useful, but it is hard to prove that it is wrong.

E. There Still Could Have Been Bargaining After the Inquiries

It is always possible that the time frame of this Article was too short: after the inquiries were complete, the parties may have made a deal. This seems unlikely; some of the inquiries were made a year or more after final judgment, and in general the situations the lawyers described seemed settled. But in the end this is another empirical question, and the possibility of some later changes in the parties' positions cannot be ruled out.

F. The Parties Might Have Disagreed with Their Lawyers

It might be revealing to talk to the parties rather than their attorneys. The accounts in this study in a sense are second-hand, and it is possible that the lawyers portrayed their clients inaccurately. Maybe they preferred to style their clients as people of principle, when perhaps all they really were doing was setting the stage for possible bargaining still to come. This seems doubtful; usually the lawyers on both sides agreed in their descriptions of both parties, and those descriptions were far from heroic-were in fact unflattering to their own clients in many instances. Given the consistency of the lawyers' accounts-within each case, where it was possible to communicate with both lawyers, and from case to case-I do not think the results would have been much different if I had spoken with their clients.

It would be particularly interesting to know what role the lawyers had in shaping their clients' views of their options, and perhaps that is information that the lawyers themselves cannot be expected to provide (though some of them did say they had tried everything they could to get their clients to consider settlement). It is conceivable that at least some of the absence of bargaining results from the lawyers' influence, rather than any settled opposition to bargaining by the parties. This raises a number of interesting questions about the appropriate role of an attorney in cases like these. If lawyers help shape their clients' attitudes toward their rights and toward bargaining, should they be pressing them to make deals by encouraging them to think of their entitlements in commodified terms? 


\section{SUMMARY AND CONCLUSTON}

A study of twenty old-fashioned nuisance cases litigated to judgment revealed no bargaining after judgment in any of them. Nor did any of the lawyers contacted believe that bargaining after judgment would have occurred if the loser had won. They attributed the lack of bargaining after judgment to acrimony between the parties and to attitudes the parties held toward their rights that made them reluctant to bargain. The size of the sample considered here is small, so it would not be wise to draw strong conclusions from these results about how nuisance cases ought to be decided. We do not know just how often these sorts of problemsof enmity and of resistance on various grounds to treating certain rights as commodities-are sufficient to foreclose the possibility of bargaining after judgment. But in view of the consistency of the results recounted here, it does seem reasonable to conclude that these problems often can be substantial impediments to bargaining after judgment in nuisance cases. These difficulties generally have been overlooked in the economic literature, which uses models of human behavior that focus instead on the danger that each side will engage in strategic behavior that may derail otherwise promising bargains. ${ }^{88}$ If a court deciding a nuisance case were to base its decision on these models of nuisance litigation and its aftermath that have been offered in the economic literature, it thus would be acting hazardously; the models exclude details that can have important practical consequences. Perhaps courts understand this. It is not clear that economic models have had an effect on the way that courts fashion remedies, at least in this area of law. If the models have not had much effect, it may be because judges can sense in them the absence of details that make a difference.

These results raise a number of questions worthy of further exploration. Why might parties have the attitudes toward cash exchanges that the lawyers in these cases describe? To what extent do similar attitudes toward cash exchanges exist in other nonmarket contexts? What stance should the law take toward the

For a partial exception, see Cooter and Ulen, Law and Economics at 100-01 (cited in note 12) (explaining that ambiguities in legal rights and the costs of monitoring any cooperative solution, as well as strategic behavior, are obstacles to successful bargaining). These results bear only a surface resemblance to the "Hobbes theorem" proposed elsewhere by Professor Cooter. See Robert Cooter, The Cost of Coase, $11 \mathrm{~J}$ Legal Stud 1, 18-23 (1982). The Hobbes theorem suggests that problems of strategic behavior will be insurmountable obstacles to the division of a surplus from bargaining. In the cases considered here, the parties did not get far enough for strategic behavior to become a problem; perhaps the problem with applying the Hobbes theorem here, then, is that it is too optimistic. 
parties' feelings in cases like these? A possible answer to the last question is that acrimony and a distaste for treating rights as commodities ought to be considered transaction costs. But the decision to classify an aspect of human preference or behavior as a "transaction cost" would have consequences of its own (it would mean using the law to extinguish the effect of those preferences and behaviors), and thus requires a defense. The behavior of the parties to these cases might seem deviant if viewed relative to a baseline of behavior by people inside markets, or behavior by corporations that may not be susceptible to emotion, humiliation, and other cognitive features of individual life outside of markets. But why use that sort of behavior as the standard to which the rest of the world should be brought into line? Maybe there are normative or pragmatic arguments that could be advanced in support of such a position; the point here, in any event, is just that if a purpose of the law is to help make the world look the way it would if bargaining were easy, then the ideas we use about human attitudes and behavior in that setting ought to be made explicit and properly defended.

Nuisance cases often involve situations where conventional transaction costs are low, and the stories told about them thus have served in some instances as sources of ideas about how the law should handle the many situations where transaction costs are prohibitive. One of the propositions to emerge from this literature is that where bargaining between legal actors is not feasible as a practical matter, the law should try to recreate the outcomes that would emerge if bargaining were easier. But if it turns out that parties do not bargain over their rights when transaction costs are low (or if we know they wouldn't because we see them refusing to bargain for reasons that have nothing to do with transaction costs in the sense of feasibility problems), then the broad project of using law to create bargains for parties when transaction costs are high becomes more complicated to defend. The problem might be avoided by abandoning nuisance cases as a paradigm-by finding some other situation where parties are more inclined to bargain and saying that is the situation the law should try to mimic when it confronts problems involving high transaction costs. But that move, too, requires a defense. If the law is going to be used to create the outcomes that would emerge in a counterfactual world, we need to know not only what the conditions are in that world, but what the people there are like, and why they have been chosen as models. It is not as if the behavior and attitudes of the parties in these nuisance cases are exceptions to some general rule of human behavior. No general rule 
for these purposes has been established, either as an empirical or normative matter.

In the meantime, however modest the sample and methodology used here may be, I hope the accounts presented in this Arti-

- cle will encourage a measure of caution on the part of economic modelers who generalize about the consequences of using property rights and liability rules as remedies. There is a parallel between the use of nuisance cases by economic analysts (including Coase) and the use of lighthouses by economic analysts (criticized by Coase). Coase undertook a study of the financing of lighthouses $^{89}$ in an attempt to show that the views of many economists rested on examples that had weak and unexamined empirical foundations. In particular, he was bothered by economists' use of lighthouses as an example of a public good that private enterprise cannot be counted upon to provide. What Coase says about the use of lighthouses by some economists is not far from what I would say about the use of nuisance cases by other economists:

Despite the extensive use of the lighthouse example in the literature, no economist, to my knowledge, has ever made a comprehensive study of lighthouse finance and administration. The lighthouse is simply plucked out of the air to serve as an illustration. The purpose of the lighthouse example is to provide 'corroborative detail, intended to give artistic verisimilitude to an otherwise bald and unconvincing narrative.'

This seems to me to be the wrong approach. I think we should try to develop generalizations which would give us guidance as to how various activities should best be organized and financed. But such generalizations are not likely to be helpful unless they are derived from studies of how such activities are actually carried out within different institutional frameworks. ${ }^{90}$

\section{APPENDIX}

Hildebrand $v$ Watts. ${ }^{91}$ Dominick DiMenco and his wife, Terry, lived next door to Carl and Florence Hildebrand in New Castle, Delaware. ${ }^{92}$ The DiMencos and the Hildebrands do not get along well, and have litigated a number of their differences over the years. This

\footnotetext{
89 See Jolls, Sunstein, and Thaler, 50 Stan L Rev at 1471, 1484, 1498 (cited in note 20).

${ }^{\infty}$ R.H. Coase, The Lighthouse in Economics, $17 \mathrm{~J} \mathrm{~L} \&$ Econ 357, 375 (1974), quoting William S. Gilbert, The Mikado.

${ }^{91} 1997$ Del Ch LEXIS 32. This account is based on the opinion in the case and on questionnaires filled out by the lawyers for both sides.

${ }^{92}$ The "Watts" in the case name is Lee Watts, the father of Terry DiMenco and partowner of the DiMencos' house; he has no other connection to the case. See id at *2.
} 
dispute involved a large light on top of the DiMencos' house. The DiMencos claimed that they put the light there in order to protect their house against vandalism and theft (they said they had been robbed of bicycles, a motor bike, and a car, and that the car was taken from the part of their driveway where the light now shines). They also were concerned about other thefts that had occurred in the neighborhood. In addition, they liked the light because it permitted their children to play outside late in the day. The Hildebrands, however, complained that the light shined into their house-that it shined (as the court explained) "into their kitchen in the evenings, and is noticeable when the kitchen lights are off, and shines into their bathroom, even though the venetian blinds are drawn so as to block light from entering the room from outside. ${ }^{93}$ The Hildebrands believed that the light was installed to spite them (the DiMencos had erected a large fence between the neighbors' properties at about the same time as they installed the light). They said that the DiMencos frequently flicked the light on and off just to harass them. The DiMencos denied this. The Hildebrands offered photographs and a videotape to support their claims. The chancery judge studied the evidence and concluded that "it is hard for me to agree, based on what I saw, that [the light] is so blinding or obtrusive as to render the bathroom and kitchen unusable to [the Hildebrands] in any realistic sense." 94 The judge noted that the light did frustrate Mr. Hildebrand's enjoyment of his back porch, but noted that the problem had become less severe since the suit began: in the meantime the DiMencos had installed some other, less intrusive lights intended to reduce the amount of time the big light needed to be kept on. ${ }^{95}$ The judge concluded that without evidence of more substantial discomfort (lost sleep, for example), he was not willing to enjoin the use of the light.

The DiMencos' use of the light has continued since the end of the lawsuit. There has been no attempt to negotiate an arrangement in which the Hildebrands might pay the DiMencos to remove the light or modify their use of it. The lawyers agreed on the reason why: "[We] tried to get the parties to negotiate, but the parties hate each other." "The parties do not get along. Every contact leads to further hostility." The lawyers also believed that if the Hildebrands had won the suit, they would not have bargained with the DiMencos to allow them to keep using the light. The DiMencos' lawyer said, "My experience in these cases (in which the parties hate each other) is that they never get resolved. The only solution is for one party to move."

Kruger $v$ Shramek. ${ }^{96}$ There is a subdivision in Omaha, Nebraska, called Eagle Run West. Eric and Ann Kruger bought a lot there in 1991. John and Tammy Shramek bought the neighboring lot about a year and a half later. The Krugers had not yet begun building their house at the time, and soon the Shrameks overtook them, constructing a home and landscaping their backyard. The Shrameks' landscaping aggrieved the Krugers, because Eagle Run West is adjacent to the Champions Golf Course in Omaha, and the Shrameks' landscaping obstructed the view of the 18th green from the patio that the Krugers had planned to build. The Shrameks made some adjustments in response to the Krugers' complaints, but the adjustments were not enough to suit the Krugers, who brought a lawsuit seeking, among other things, an injunction requiring that their view be restored. ${ }^{97}$ The trial court rejected these claims, and the court of appeals affirmed, holding that "a lawful building or structure, including landscaping improvements associated with any such building or structure, cannot be complained of as a private nuisance merely because it obstructs the view of neighboring property. ${ }^{98}$

Id at $* 12$.

or Id at $\% 15$.

${ }_{95}$ The Hildebrands complained about one of these lights, too, but the court refused to consider the claim. The DiMencos insisted that the light in question, attached to a shed in their back yard, was activated by a motion sensor-which was why it created the flickering effect that vexed the Hildebrands.

${ }^{96} 5$ Neb App 802, 565 NW2d 742 (1997). This account is based on the opinion in the case and on questionnaires filled out by the lawyers for both sides.

${ }^{97}$ The Krugers also argued that the Shrameks were violating terms of restrictive covenants they had signed, but the court rejected these claims.

${ }^{98} 565$ NW2d at 747. 
Once the lawsuit settled the parties' rights, there was no exchange afterwards and no discussion of the possibility of an exchange. "The parties weren't talking," the plaintiffs' lawyer wrote. "Typical neighborhood dispute in which personalities get mixed in-the transaction cost the Brits call bloody mindedness." Likewise, according to the defendants' lawyer, "The parties were so hostile that they could not agree on anything." The defendants' lawyer also revealed that the plaintiff "is a practicing attorney in Omaha. Even though he hired an attorney of record he was really his own attorney and he had a fool for a client." Even if the court had found a nuisance and ordered the Shrameks' trees removed, neither lawyer thought there would have been any bargaining over that order, either.

Ritchhart $v$ Gleason. ${ }^{99}$ Gary and Elaine Gleason owned a mobile home park in Ross County, Ohio. It was wiped out by a flood. They received some money from FEMA and the Small Business Administration to rebuild it elsewhere. They found a parcel of land that seemed suitable, bought it, and started building. They borrowed $\$ 480,000$ to purchase and install a sewage treatment plant, obtained the necessary permits to operate it, and began discharging effluent from the plant into a ditch-a ditch that ran across the property of Wayne and Renick Ritchhart. The Ritchharts were worried that the effluent might settle in the ditch (which otherwise was dry 90 percent of the year). They sued, claiming that the effluent constituted a nuisance and a trespass and seeking an injunction against its further discharge into the ditch. The trial court granted the injunction, and the court of appeals affirmed.

Since the court entered judgment, the Gleasons have paid to have the waste from the park trucked to a treatment facility elsewhere. The parties have not discussed the possibility that the Gleasons could pay the Ritchharts for the right to discharge the effluent into the ditch. The plaintiffs' lawyer said he did not know what would have happened if the defendants had offered to buy the rights from the plaintiffs after the suit was over. Such a possibility "never came up," and he had trouble imagining it. "This came to be a very emotional issue for the parties. It's hard for me to fathom a situation where the defendants would write a check for anything to my clients." He said that "the defendants had been counseled by their attorney that a state permit was all they needed, that [their case was] a dead-bang winner. They claimed the original suit brought was frivolous," and these charges caused both sides to dig in their heels.

Another problem was that the Gleasons never talked to the Ritchharts about their plans; the Ritchharts' lawyer thought this also hurt the possibility of any negotiation after judgment. "The property owners were annoyed because [the defendants] could have asked. Maybe a deal could have been more easily worked out in advance. But then the battle lines were drawn." He said that if he had been counseling the defendants in advance, he would have advised them to act differently. "Particularly in a rural community, you do the neighborly thing and knock on doors and explain what you're going to do. I think it would have made a big difference. Our clients weren't out to make a buck over the whole thing. They were concerned about their rights." He thought that similar views about bargaining were held on the other side, identifying two reasons why he thought there was no bargaining. "One was principle; the other was finances. [The defendants] had put every nickel they had into the park" and wouldn't have wanted to pay the plaintiffs for the right to use the trench behind their property.

The Ritchharts' lawyer did not think there would have been any bargaining if the Gleasons had won the case-that is, if the court had vindicated their right to discharge waste into the ditch. "If [my clients] had lost, I don't see that they would have paid [the defendants] to go away. The volume [of flow] was low enough that it wouldn't have made a big difference to them."

McCombs u Joplin 66 Fairgrounds, Inc. ${ }^{100}$ This was a racetrack case arising in an un-

99 Ohio App 3d 652, 672 NE2d 1064 (1996). This account is based on the opinion in the case, and on a questionnaire filled out by the plaintiffs' lawyer and a telephone interview with him (Jan 20, 1998).

${ }^{100} 925$ SW2d 946 (Mo App 1996). This account is based on the opinion in the case, questionnaires filled out by lawyers for both sides, and a telephone interview with the de- 
zoned area on the outskirts of Joplin, Missouri. Joplin 66 bought a one hundred acre lot of land there and built a dirt auto racetrack $3 / 8$ of a mile long; the lawyer for the racetrack estimated that it had cost approximately $\$ 1.5$ million. On one side of the racetrack were commercial and manufacturing buildings; on the other were houses, though the nearest house was several hundred feet away. There were 46 houses within a half-mile of the racetrack, 301 within a mile of it, and a total of 2,762 residents living within a two-mile radius.

Before building the track, Joplin 66 sought a declaration that it would not be creating a nuisance; the request was rejected as premature. Once the track was up and running, twenty-eight residents from the surrounding area joined as plaintiffs in a lawsuit seeking to enjoin the races as a nuisance. Joplin 66 offered to buy the houses closest to the track, but an agreement could not be reached; the owners demanded premiums for their homes, which the track would not pay.

The court granted the injunction in part, placing some restrictions on the noise and dust the track would be allowed to generate and on the length and number of races the track would be allowed to conduct. The court also required the racetrack to ensure that the race cars were fitted with certain types of mufflers.

According to both lawyers, there have been no negotiations between the parties about the possibility of modifying the court's order-no discussions of the possibility that the residents might pay the racetrack to scale back its operations further or that the racetrack might purchase permission to operate outside the restrictions imposed by the injunction. The racetrack has not considered such possibilities, according to its lawyer, though "the race track operator believes he has been unduly restricted and the owners are disappointed because they didn't get it closed completely." The racetrack's lawyer did not believe there would have been any bargaining after judgment if the racetrack had won the suit outright. While it seemed likely that the race cars might have installed the mufflers without a court order (because other racetracks required the mufflers), he did not think there would have been an offer to pay the track to operate less frequently. And he did not think the residents could have afforded to buy out the racetrack altogether.

Nor did the defendant's lawyer believe there would have been bargaining if the racetrack's operation had been enjoined altogether. It was "an emotional kind of case" for the residents who lived near the track, and he "guaranteed" that they would not have taken money from the racetrack to allow it to operate if it had been enjoined. "Some of [the residents] were people of means," and "were at the stage of their lives where money isn't as important as quality of life." And there were "hard feelings" besides: the racetrack's lawyer said that if a broader injunction had been entered and affirmed, "I expect the owners would have tried to think of something else offensive to do with the land." (They had talked of starting a trailer park there if the racetrack were shut down.)

Slavant $v$ Calhoun Motor Speedway. ${ }^{101}$ Yet another case about a racetrack. Thirtynine homeowners in Calhoun, Louisiana brought a nuisance suit against a local speedway. The plaintiffs testified about the inconvenience and mental anguish they suffered as a result of the noise and dust the speedway created on Friday nights. There were traffic jams leading to and from the speedway before and after the races; in addition to noise from the races themselves, country and western music was broadcast over the speedway's public address system. Some of the plaintiffs said that a "funnel cloud" of dust would originate on the racetrack and then sweep across their property about two hundred feet away.

The trial court concluded that the speedway created dust and noise that materially impaired the plaintiffs' enjoyment of their homes and issued an injunction that placed various restrictions on how much of each the speedway could generate. Some of the restrictions tracked a local ordinance restricting noisemaking; the court created others from scratch. (The court of appeals added awards of $\$ 1,000$ apiece to the four plaintiffs living closest to the racetrack to compensate them for past harm.) After judgment, the speedway was sold to another operator. The new owner ran the racetrack for two summers, then

fendants' lawyer (Mar 13, 1998).

${ }^{101} 626 \mathrm{~S} 2 \mathrm{~d} 771$ (La App 1993). This account is based on the opinion in the case and telephone interviews with the lawyers for the plaintiffs and the defendants (July 9, 1996). 
closed it down-due in part (the lawyers agreed) to the dogged efforts of the plaintiffs to enforce the restrictions of the injunction by initiating contempt proceedings.

The racetrack's owners suggested the possibility of settlement both before and after judgment. One of the couples expressed some willingness to go through with this if the racetrack's owner were willing to buy their house and pay a premium: perhaps 20 percent more than the house's market value. The racetrack's owner was not willing to consider this, and the negotiations went no further. The other couple involved refused to consider being bought out; they considered their house their "dream home." The husband was a factory worker, and his wife was a former secretary who had quit her job in order to raise their daughters. They had moved to the country and built their house there; they had been surprised when the racetrack was built without warning. "That's how it started, and right away they started hating each other," the plaintiffs' lawyer said. "A lot of personalities came into play." The plaintiffs' lawyer said that his clients could not have afforded to pay the speedway to scale back its operations if they had not obtained the injunction, and he believed the plaintiffs would not have considered letting the racetrack pay to be free of the injunction's terms. "They didn't want money. They wanted to get rid of the noise," the speedway's lawyer said. The plaintiffs' attorney agreed. "We've got good old solid country people out there. They don't care about the bucks too much," he said.

Sharp $v$ 251st Street Landfill, Inc. ${ }^{102}$ 251st Street Landfill bought a 320-acre parcel of land in Okmulgee County, Oklahoma with the intention of building a landfill there. Six neighboring landowners brought a lawsuit seeking to enjoin creation of the landfill as an anticipatory nuisance. They claimed that the landfill was likely to generate noxious fumes and cause contamination of nearby ground and surface water. The plaintiffs won a preliminary injunction against the creation of the landfill, then a permanent injunction. The state supreme court affirmed: "given the demonstrated sensitivity of the water resources in the area, and the probability operation of the proposed landfill would pollute the water resources of at least some of the appellees, we believe no reversible error occurred by the grant of a permanent injunction."

The landfill has not been built, and there has been no discussion between the parties of the possibility that the defendant might purchase the right to build the landfill after all. The plaintiffs' lawyer said there was no point in such discussions because the parties "were so far apart they had no interest in talking." There had been brief attempts at settlement negotiations, but they had not been productive; the parties "said rude things to each other and then left." When asked about the amount plaintiffs might have accepted to allow the landfill to be built, the attorney did not know: there was "no real interest in determining an amount." I asked whether it might not make sense for the plaintiffs to consider bargaining over a possible division of the profits from the defendant's proposed landfill. The plaintiff's' lawyer said that 'from some law and econ point of view, that's what the rational solution would be, but perhaps because we're more primitive here, people were taking a different conception of property rights-they just didn't want fumes and contamination interfering with their property rights." He thought the landfill company took a similar view: its owners felt entitled to use the land as they saw fit and would have strongly resisted the idea of paying the plaintiffs beyond what they already had paid for the site. The plaintiffs' lawyer also was sure that if the landfill company had won the case, there would have been no discussion of the possibility that the plaintiffs might buy the land or otherwise pay the company to build elsewhere, although some of the plaintiffs might have moved away. "Negotiating as a concept didn't have much appeal," he said.

Parker $v$ Ashford. ${ }^{104}$ William Parker bought fifteen acres of land in Shelby County, Alabama in the early 1970s, and was living on them in 1994 when he bought an adjacent parcel of twenty acres. He began to build a dirt racetrack on his new property. This upset

${ }^{102} 925 \mathrm{P} 2 \mathrm{~d} 546$ (Okla 1996). This account is based on the opinion in the case and a telephone interview with the plaintiffs' lawyer (Feb 12, 1998).

${ }^{103} \mathrm{Id}$ at 556.

${ }^{104} 661 \mathrm{~S} 2 \mathrm{~d} 213$ (Ala 1995). This account is based on the opinion in the case and on telephone interviews with the lawyers for the plaintiffs (May 23, 1996) and defendant (June 6, 1996). 
two groups of neighbors: a pair of couples who lived within one hundred feet of the racetrack and a group of between twenty and thirty others who lived in a housing development between a mile and a mile and a half from Parker's property. One of the latter neighbors was a flight instructor, and one of his students was a partner at what became the plaintiffs' law firm. The lawyer put together a lawsuit on behalf of the neighbors. The court found that the racetrack would be a nuisance and entered an injunction against its construction. It based this judgment primarily on testimony about the amount of noise, light, and dust the track would create for the neighbors living immediately next door.

Before the suit was filed, the plaintiffs' attorney met with the neighbors, and then went to Parker and made an offer to buy the land at a price that exceeded its market value. He suggested that Parker could use the money to build the track elsewhere, and that after buying the property the neighbors would be willing to dam it and turn it into a lake. Parker said he wasn't interested. Auto racing was his hobby, and he had long wanted to have a racetrack next to where he lived. Parker told the plaintiffs that if he couldn't build a racetrack, he would sooner turn the land into a pigsty than sell it to them. (This was a clue that-as the lawyers went on to say-Parker would not have sold the rights to the plaintiffs if he had won the case.)

There never were any discussions-between the plaintiffs and Parker, or among the plaintiffs, either before the litigation or after the injunction was obtained-of selling Parker the right to build the track. One of the homeowners did say he would be willing to sell his house to Parker, but for a price that Parker considered prohibitive. After judgment, the land remained an empty crater, still owned by Parker.

The court did not discuss the dollars involved, but Parker's lawyer believed that the racetrack would cost more than $\$ 100,000$ to build; he did not know how profitable it would have been. Although it would have been hard for Parker to afford to buy out the plaintiffs, his lawyer said, Parker was simply not interested in paying anyone for what he considered the exercise of his rights. The plaintiffs' lawyer agreed: if Parker had won, the only way to stop him would have been to buy out his land, and the personalities involved would have made it impossible. Parker hated the plaintiffs, and would not have accepted any amount of money from them. On further reflection, however, the plaintiffs' lawyer supposed that if he had won perhaps Parker would have accepted several million dollars to forego building the racetrack, but he would not have accepted any amount that the plaintiffs would have considered paying him.

$O^{\prime} C a i n v O^{\prime} C_{a i n} .^{105}$ The parties to this suit were family members in South Carolinamost of them cousins, and most of them named O'Cain. The late Henry O'Cain left adjacent pieces of land to his two sons, Lever and Harold. The properties were roughly separated by a road, but only roughly. At one point where the road departs from the boundary line, the property owned by Harold's family is separated from the road by a strip of land, about fifteen feet wide, belonging to Lever's family. This dispute primarily involved that strip of land, but a bit of background is necessary before getting to that part of the story.

The facts are rather intricate. Before his death in 1991, Harold O'Cain leased a portion of his property to some members of Lever's family for use in raising hogs; in return, Lever's family gave Harold's family one hog per year. Once Harold died, his children planned to divide the family property among themselves, and a dispute arose over whether the members of Lever's family should be allowed to continue raising hogs on the leased property. Lever's family suggested that Harold's family buy the strip of land at issue in this case-the strip owned by Lever's family separating Harold's property from the road.

The dispute turned ugly. Lever's family built a wire fence along the property line; the fence obstructed driveways that connected the road to houses on Harold's land. Members of Lever's family put cans, buckets, and a toilet tank on the fence posts. They also posted signs displaying the ten commandments, "Entering Hell," and various unkind sayings about Harold O'Cain's family.

${ }^{105} 322$ SC $551,473 \mathrm{SE} 2 \mathrm{~d} 460$ (1996). This account is based on the opinion in the case, questionnaires filled out by the lawyers for both sides, and a telephone interview with the lawyer for the Marion O'Cain family (Mar 12, 1998). 
Finally, Lever's son, Marion, removed the family hogs from the land the family had been leasing from Harold's family. Nobody in Harold's family had told Marion that he had to do this, but Marion said that he saw it coming. He testified at trial that "I did not say a word, "cause I knowed what to do about them "cause we had land to put them on, and that's what I did when we got the line surveyed." When Marion said "we had land to put them on," he meant that the hogs could be moved onto the strip of land his family owned between the road and the houses where Harold's family lived. And that is what he did: he put the hogs just inside the fence he had erected, in front of the homes where Harold's family lived.

Harold's family sued Lever's family, claiming that the driveways should remain open and that the hogs were a nuisance because they attracted flies and created pungent odors. With respect to the driveways, the trial court found that Harold's family had a valid easement; the court of appeals affirmed. As for the hogs, Marion O'Cain said that the reasons for putting the hogs there were threefold: "to keep the grass and weeds down" on the land; "for them to have some exercise and walk"; and "[y]ou paying taxes on [the land] and you got to use it for something." He further explained that other land on his property would not be suitable for raising the hogs because the other areas already had "feeders and concrete poured and wire there."

The Master in Equity, one O. Davie Burgdorf, determined that the hogs were not a nuisance because they "only adversely affected the aesthetics of the home." ${ }^{106}$ He did not believe that moving the hogs had caused any actual increase in flies and odors. The court of appeals disagreed, however, finding that "[t]he defendants have, indeed, placed 'the pig in the parlor instead of the barnyard," and that "[a] person of ordinary tastes and susceptibilities would clearly find such a situation objectionable." ${ }^{107}$ The court rejected the defendants' claims that they had no better place to raise the hogs than in front of the plaintiffs' houses, and further noted that there was evidence that the defendants had been acting maliciously, as the plaintiffs claimed. The court enjoined the placement of the hogs in front of the Harold $O^{\prime}$ Cain family's homes.

There was no negotiation after judgment over the possibility of keeping the hogs in front of the houses owned by Harold O'Cain's family; Lever's family just moved the hogs further down the strip of land. Neither lawyer thought there would have been any bargaining if the case had been decided in favor of the defendants, either. The issue ultimately was made moot by the departure of Harold O'Cain's family (the parties who won the suit) from the area. They now rent out the property for farming purposes, and have brought another lawsuit against Lever O'Cain's family for defamation arising out of the signs mentioned earlier. (The defendants' lawyer felt confident that this suit would not be settled, either; at this writing, he was preparing a First Amendment defense for his clients.)

The lawyers for both sides said that they had tried their best to work out a settlement. Indeed, Harold's family offered to give to Lever's family the land they had been leasing to raise hogs in exchange for Lever's agreement to remove the hogs from in front of their houses. The defendants' lawyer said: 'The lawyer who represented [the plaintiffs] and myself have continuously made efforts to settle these cases but our clients simply refuse to do anything that is suggested by the other side." The plaintiffs' lawyer concurred: "As to why the defendants were unwilling to entertain any settlement offer, I feel that they were uneducated and would not take the advice of their lawyer regarding the legal issues involved. In addition, it became apparent that they felt that they could do anything with their land without regard to the consequences to other adjacent landowners. They were just very hardheaded about the entire matter and it became an emotional issue rather than a legal or business decision."

Both lawyers considered the case atypically nasty. The defendants' lawyer wrote that "[b]ecause this was a family dispute, there is a tremendous deal of animosity between my clients and [the plaintiffs]." He also wrote, however, that "most property line disputes that I have ever been involved in was [sic] a result of animosity between the parties involved. It

${ }^{106}$ This was the appellate court's statement of the Master's reasoning. 473 SE2d at 464.

${ }^{107}$ Id at 467. 
doesn't seem to matter whether those parties are family members or strangers but the property line dispute solidified their feelings of dislike and/or hatred of the other party." 'The plaintiffs' lawyer wrote that '[w]e live in a predominantly rural and agricultural area. We do not have county wide zoning and property rights are a hot' issue." Nonetheless he thought that "these defendants were rather unique in their views and that we could have reached a settlement with just about anyone else."

Sedman $v$ Rijdes. ${ }^{108}$ Charles and Ellen Sedman live in North Carolina; on their property they have a collection of fruit trees. For several years they lived next to an organic farmer who had a number of cypress trees on his property. These cypress trees conveniently shielded the Sedmans' property from Multiflora Greenhouses, Inc., a firm that raises and sells plants and vegetables. However, Multiflora eventually bought the intervening property and removed the cypress trees, leaving the Sedmans' property exposed to the noise generated by thirty-seven large exhaust fans attached to Multiflora's building. The Sedmans brought a lawsuit, raising nuisance claims and alleging zoning violations.

Before trial the parties went through a required mediation process; according to the plaintiffs' lawyer, it did not help. From the point of view of his clients, Multiflora was not willing to make sufficient accommodations. The Sedmans' lawyer said there were settlement negotiations prior to judgment, but these discussions never involved a proposal that the Sedmans would pay anything to Multiflora. Rather, the question was whether Multiflora would make unilateral accommodations to end the dispute. At one point Multiflora suggested that it might buy the Sedmans' property: each side would obtain an appraisal, and they would negotiate from there. The Sedmans decided that they didn't want to move because they liked their trees and Mr. Sedman is emotionally attached to his property.

The trial court gave summary judgment to Multiflora on the zoning claims; the court then submitted the nuisance claim to the jury. The Sedmans' lawyer felt he had a difficult case because the noise from Multiflora's fans was "low frequency": it did not register significantly in decibels but was the "kind of noise that will drive you crazy"; it caused the Sedmans' windows to shake and their floor to vibrate. The jury found for Multiflora. The Sedmans only appealed the judgment on the zoning claim; the court of appeals affirmed.

There have been no negotiations about the possibility that the Sedmans might pay Multiflora to modify or replace the fans so that they make less noise, the Sedmans' goal in the lawsuit. The Sedmans' lawyer believes such adjustments could be made, but that they would be expensive and that his clients could not afford to pay Multiflora to make them.

If the Sedmans had obtained an injunction ordering the replacement or adjustment of the fans, would the Sedmans have entertained offers from Multiflora to pay to be released from the injunction? The defendants' lawyer said that although he didn't think an injunction would have resulted in payments by the defendants to the plaintiffs for the right to continue running the noisy fans,. "a solution would have likely been negotiated to deal with the worst elements of the adjoining use, and to limit its expansion." The Sedmans' lawyer said no payments would have been made in that situation, and indeed no bargaining at all. Why? For one thing, "they hate each other." For another, "the realities of these situations are that you've got lots of feelings and circumstances that aren't necessarily 'rational.' In this situation you've got years of bad blood, and nobody's going to be able to put a price" on the rights involved. In addition, both sides have their "pride" on the line; "each of them is feeling indignant and self-righteous." He characterized Multiflora's owner as taking the position that " $[\mathrm{b}] \mathrm{y}$ God, this is my land, and you've got nothing to say about it," and his own client's position as, "Tve put all this into my property, and now you're getting rich at the expense of your neighbors." The fans continue to blow.

Langan $v$ Bellinger. ${ }^{109}$ Julie Langan and Ernest Eggers each own houses in Schoharie, New York about 250 feet away from a Presbyterian church. They filed a complaint seeking

${ }^{109} 127$ NC App 700, 492 SE2d 620 (1997). This account is based on the opinion in the case, a questionnaire filled out by the defendants' lawyer, and a telephone interview with the plaintiffs' lawyer (Mar 12, 1998).

${ }^{109} 611$ NYS2d 59, 203 AD2d 857, (1994). This account is based on the opinion in the case, and telephone interviews with the plaintiffs' lawyer (May 24, 1996) and an assistant to the defendant's lawyer (May 1, 1998). 
to enjoin the church "from playing hourly chimes on a daily basis beginning at 8:00 o'clock in the forenoon and ending at 8:00 o'clock in the afternoon ... and from playing carillon music on a daily basis at 12:00 o'clock in the afternoon and at 6:00 o'clock in the afternoon." 110 Langan alleged that the noise from the church "is a complete disruption of [her] family life, prevents a child from sleeping, and invades the privacy of [her] residence and creates unnecessary stress."

While the church submitted numerous affidavits stating that the bells were not unusually loud, disruptive, or unlawful, the plaintiffs failed to submit any evidence other than their own affidavits. The trial court gave summary judgment to the church, and the court of appeals affirmed.

According to the plaintiff's lawyer, the church had offered to settle the case prior to litigation-not for cash, but by voluntarily ceasing to ring of the bells at certain times of day. The plaintiffs did not accept the offer; nor did they offer money to the church to stop ringing the bells, either before judgment or afterwards. The plaintiffs' lawyer did not think that if his clients had won an injunction of some sort, the church would have paid them for permission to ring the bells as before. "That never would have occurred, believe me," he said.

44 Plaza, Inc v Gray-Pac Land Co. ${ }^{112}$ A stretch of Interstate 44 in Franklin County, Missouri, not far from St. Louis, runs through the city of Pacific, where the sale of fireworks is legal. In 1989 a man named Brown, doing business as a company called 44 Plaza, Inc., bought a large parcel of land just off the highway-roughly thirteen acres-for $\$ 164,000$, and built a store there to sell fireworks, beer, cigarettes, and gasoline year round. The store made most of its money selling fireworks in the weeks before the Fourth of July. A few months later a company called Gray-Pac Land Company-owned by people named Kell-came along and bought, for about the same price, a much smaller piece of land (a little less than an acre) immediately adjacent to the highway on one side and to 44 Plaza's store on the other. Gray-Pac only used the land for two or three weeks before the Fourth of July, at which time it set up a large tent and sold fireworks. Early in its existence, Gray-Pac put up large signs advertising its fireworks, which had the happy (for Gray-Pac) and indeed purposeful effect of blocking the view of 44 Plaza's store from the highway. 44 Plaza sued Gray-Pac, claiming the signs were a nuisance.

The trial court ruled that Gray-Pac's signs were a nuisance because they were installed for "malicious purposes," namely to block the view of 44 Plaza's business from the road. ${ }^{113}$ The court of appeals reversed, holding that Gray-Pac had not infringed any rights held by 44 Plaza and reasoning that a landowner has no right to a view of its property. Rejecting the idea of liability for erection of a spite fence, the court refused to inquire into the defendant's motives for committing a lawful act.

While the appeal was pending, Gray-Pac removed its signs (the only alternative was to post a supersedeas bond that its lawyer described as prohibitively expensive, although he could not remember its amount) and erected alternative obstructions. First Gray-Pac added to its land a row of twenty-five tall (twenty foot) evergreen trees to obscure the view of its competitor from the road. 44 Plaza obtained an order from the trial court requiring that the trees be removed, pending the appeal. In response, Gray-Pac pulled down the trees and hung from a crane a giant American flag, creating the same effect as the signs and trees. Gray-Pac reasoned that a court would pause before ordering removal of a flag. Before the court could reach that issue, however, the appellate court decided in favor of Gray-Pac on the matter of the signs. So Gray-Pac took down the flag and put its signs back up. (While the appeal was being decided, Gray-Pac had decided what to do if it lost and was forced to take down its signs: it would set up a permanent building that would have the same obstructive effects as the sign, and pay a girl to sit inside year round, per-

${ }^{110} 611$ NYS2d at 59 (ellipses in original).

${ }^{111}$ Id at 59-60 (alteration in original).

${ }^{112} 845$ SW2d 576 (Mo App 1992). This account is based on the opinion in the case and telephone interviews with the lawyers for the plaintiffs (Aug 1996) and defendants (Aug 20,1996 ).

${ }^{113}$ Id at 578. 
haps selling cigarettes. They reasoned that no court would dare shut down an operating business as a spite fence.)

Following the appeals court ruling, Gray-Pac left its signs in place, even after the fireworks season ended and its tent was gone, so that the view of 44 Plaza's store was obstructed year-round. 44 Plaza complained to the state highway department that GrayPac's signs violated state law that permits only signs that advertise "on premises" sales. During eleven months of the year Gray-Pac had no such "on premises" sales. Gray-Pac, however, found a provision of the highway regulations defining "on premises" as "within 12 months" - and Gray-Pac's sales of fireworks never were more than 12 months away. So the signs stayed up, and Gray-Pac prominently added the word "CLOSED" to them-primarily to infuriate 44 Plaza by reminding them that the signs were serving no purpose other than to block the view of its store from the highway. The signs also had the effect of leading people to think that 44 Plaza's store was closed, since the signs were near 44 Plaza's store.

44 Plaza attempted to make itself visible using signs of its own; Gray-Pac, however, moved its signs to compensate. A year or so later, Gray-Pac replaced its temporary tent with a permanent store of its own to sell the usual roadside items. The building was a twostory edifice smaller than 44 Plaza's. 44 Plaza responded by moving its gas pumps as close as it lawfully could to its property line. This did not violate any laws, but it made it impossible for Gray-Pac to renew its license to sell fireworks because the license would have violated fire codes forbidding the sale of fireworks within 50 feet of gas pumps (as 44 Plaza pointed out to the fire department). Gray-Pac obtained a variance from this provision during the first year after the gas pumps were moved by promising not to keep any fireworks in the back of its building. After that year no further waiver was available, however, so to avoid 44 Plaza's gas pumps, Gray-Pac tore down its building and moved it further away at a cost that Gray-Pac's lawyer estimated to be about $\$ 100,000$.

The lawyers said there were no settlement discussions that came close to succeeding. Each side made early statements to the effect that they might be willing to buy out the other, but neither was willing to consider being bought out. During the litigation, $44 \mathrm{Plaza}$ offered Gray-Pac about $\$ 300,000$ for its land; similarly, Gray-Pac offered 44 Plaza between $\$ 500,000$ and $\$ 600,000$ for its land and store. While Gray-Pac's offer seemed closer to being successful, it also contained a condition requiring that 44 Plaza not compete within a mile or so of Gray-Pac's location. 44 Plaza said this was out of the question. The lawyers conceded that there probably was some very large amount that 44 Plaza would have accepted to sign such an agreement, but Gray-Pac would not have paid it because it did not trust 44 Plaza. Indeed, it worried that 44 Plaza might find some ruse-such as changing its name-that would allow it to sneak back into the area.

The location at issue was important because fireworks were becoming harder to sell in other towns in the vicinity (a nearby city had just banned them, causing another of GrayPac's operations to close). Each side was afraid that if it relinquished its spot, it would be hard to replace, particularly if it signed a noncompete agreement. It would amount to "selling the goose that laid the golden eggs," as one of the lawyers said, and the value of the goose was too hard for the parties to estimate for either of them to want to sell. GrayPac's lawyer said he was sure his client would have demanded a price somewhere in the seven figures to give up its land, and 44 Plaza would not have considered paying such a sum.

There never were any discussions of the possibility that 44 Plaza would pay Gray-Pac to take down or move its signs, or for that matter the possibility that Gray-Pac would pay 44 Plaza to keep its gas pumps away from Gray-Pac's building so that Gray-Pac wouldn't have to tear it down and rebuild. The lawyers laughed off the idea of such negotiations, saying the chemistry between the parties would have made them impossible. They described the parties as "hotheads" who could not be gotten into the same room together. During trial, representatives of each party had indeed been left alone to try to work out their differences; but Mr. Brown "went ballistic", and when the lawyers returned he had Mr. Kell by the throat and was threatening to "pulverize" him. That member of the Kell family died later in the year of other causes, but the incident left a bad taste in the mouths of the surviving Kells. 
When I raised the possibility of a negotiation between the parties limited to the removal or relocation of the trees and signs, the lawyer for 44 Plaza had this to say: "You probably don't understand this if you've had no experience of how it is out in the country, but when you get into boundary line disputes between people, I've seen cases where it was a dispute over six one-hundredths of an acre, no more than a few hundred bucks worth of land, and people fight over as if it were gold. There's something about property that seems to bring out the worst in people." But the problem wasn't only that it was a property dispute. He said that while the fireworks business "isn't quite like the mafia, it attracts rogues."

Karpiak $v$ Russo. ${ }^{114}$ The Russos ran a landscaping supply business. A group of their neighbors, eight in all, brought a lawsuit complaining that the Russos' business was a nuisance and violated local zoning ordinances. They were distressed by the noisy machinery the business used to load its products onto trucks, by the odors created by the manure and decaying mulch that the business sold, and by dust from bark, limestone, and topsoil that blew onto their properties. The trial court dismissed the zoning complaints because the plaintiffs had not properly notified the municipality of their action, and the court nonsuited the plaintiffs' nuisance claims on the ground that the harm they alleged was not serious enough. Most of the plaintiffs worked away from home during most of the hours when the landscaping business was open; most of them could not point to any quantifiable damages they had suffered from its operation. There also were other businesses of other kinds in the neighborhood, and the road where the business was located already carried noisy traffic.

The plaintiffs' lawyer said there was no bargaining after judgment-no attempts by the plaintiffs to make a deal with the Russos to move their business or change its manner of operation. He said that one reason for the lack of interest in such bargaining was that after pursuing the lawsuit, his clients were "at the end of their rope financially"; and he expected that the defendants would have demanded an "unreasonable amount" to move. But he also said that if his clients had won the case, he did not think they would have bargained with the Russos. He said the plaintiffs and defendants had been fighting for many years and characterized them as "the Hatfields and the McCoys." He said that his clients were "uncompromising in wanting these people [the Russos] gone. ${ }^{115}$

Gianoli v Pfleiderer. ${ }^{116}$ The Gianolis and Pfleiderers used to be neighbors. One of their lesser ongoing disputes involved an easement over the Pfleiderers' lot for driveway purposes. The Gianolis brought a lawsuit claiming that the Pfleiderers stored too many vehicles on their property, interfering with the Gianolis' use of their driveway easement. The trial court agreed, and entered an injunction limiting the number and type of cars the Pfleiderers could store on their property. The court of appeals affirmed. More notably, the case also involved successful claims by the Gianolis based on invasion of privacy and intentional infliction of emotional distress. These claims were based on various unsavory activities undertaken by the Pfleiderers: "stalking" the Gianolis, ${ }^{117}$ interfering with the Gianolis' attempt to refinance their home, and making obnoxious telephone calls to the Gianolis. The court ordered the Pfleiderers to either pay the Gianolis $\$ 200,000$ in punitive

${ }^{11} 450 \mathrm{~Pa}$ Super 471,676 A2d 270 (1996). This account is based on the opinion in the case, and a telephone interview with the plaintiffs' lawyer (Feb 25, 1998).

${ }^{115} \mathrm{~A}$ year later, in a proceeding before the local zoning board, the plaintiffs finally succeeded in obtaining a ruling that the landscaping business violated local zoning laws. The company was given a year to wrap up its operations at the site, and did so; in 1998 it moved to elsewhere in the town. Ordinarily I did not consider cases that involved zoning claims, because when a zoning claim is successful the municipality has an interest in its enforcement and the defendant cannot bargain its way out of it by dealing with the plaintiff. This case was an exception because the nuisance claims were pressed and defeated separately from the zoning claims, which did not succeed until they were litigated in a different forum two years later.

${ }^{116} 209$ Wis $2 d 509,563$ NW2d 562 (Wis App 1997). This account is based on the opinion in the case and a questionnaire filled out by the lawyer for the plaintiffs.

${ }^{117} 563 \mathrm{NW} 2 \mathrm{~d}$ at 566. 
damages or to sell their house and move away.

The Pfleiderers sold their house and moved away. Unsurprisingly in view of the parties' bad feelings toward each other, there was no discussion after judgment of modifying the court's ordex - for example, by arranging for a payment by the Pfleiderers to the Gianolis of something less than $\$ 200,000$ for the right to stay in their house. Because of the "extreme animosity" between the parties, the Gianolis' lawyer said that no bargaining was likely after judgment regardless of what the court said. "The parties had been pushed-hard-by the trial judge to work out a solution by agreement," he said. "These efforts came close-then failed." After this, "there was no further attempt to negotiate. The battle lines were drawn!"

Ross $v$ Shpirt. ${ }^{118}$ The Shpirts bought a house next door to Ross. They began trying to enlarge their house, but their work did not comply with various conditions that had been set by the local property owners' association. The Shpirts demolished part of their house (or perhaps inadvertently allowed a retaining wall to collapse) and allowed the property to fall into a state of disrepair. Ross brought suit against the Shpirts on several grounds, including the Shpirts' failure to comply with the association's conditions and some nuisance claims.

The nuisance claim was based on the accumulation of garbage on the property, the existence of garbage containers and portable toilets in front of the house, the presence of construction materials, weeds, broken windows, and stagnant water on the property, and construction noise from 7 a.m. until 6 p.m. Ross also alleged entitlement to an easement "consisting of an unobstructed view to the south and west of the Ross Property, i.e. of Laurel Canyon and the City of Los Angeles." 119

On June 5, 1990, shortly after Ross had a meeting with the Shpirts about their proposed construction, music was blasted from the Shpirts' property from 7 a.m. until 10 p.m. at night. The music could be heard even with the windows closed. When Ross complained to the Shpirts, they responded by adding a second radio on a property they owned on the other side of Ross. The devices playing the music appeared to be on timers since they started every morning at $7 \mathrm{a}$.m. Ross reported the disturbance to the police on more than one occasion and asked the Shpirts to turn the volume down several times. He wrote a letter to the Shpirts informing them that the music was "interfering with my sleep and peaceful enjoyment of my premises[.]" He also obtained a temporary restraining order, which the Shpirts ignored. The music playing ended sometime between the end of June and the early part of July, after Ross obtained a preliminary injunction. ${ }^{120}$

Ross also attested to the general state of disrepair at the Shpirt premises and showed pictures of construction debris, accumulated trash, overgrown weeds, and a partially demolished structure. Ross testified that he had "anxiety," when he viewed appellants' house, and that he was "embarrassed" and "angry." He testified that it "affects [his] personality ... it's like being forced to live next to a junkyard," and has "a radical effect on [his] whole mental state every time [he] has to take a look at it and know what's gone on and what [they]'ve gone through, and what it appears [they] will have to continue to go through for God knows how long." He referred to the inability of being able to use his back yard or entertain because of the mosquitos, and the "whole anxious, irritating mental state" that "goes along with having to view it and see it. . . . You can't miss it, so its a constant source of aggravation and embarrassment and humiliation of unnecessary explana-

${ }^{118} 59$ Cal App 4th 885, 69 Cal Rptr 2d 521 (1997). This account is based on the opinion in the case, and on telephone interviews with the lawyers for the plaintiffs and the defendants (June 10, 1998).

${ }^{119} 69 \mathrm{Cal}$ Rptr 2d at 524. The homeowner's association also sued the Shpirts, but that part of the case was settled before trial. "Under the agreement, the Shpirts agreed to pay the sum of $\$ 35,000$ to [the association] for failure to maintain their property in neat, clean, and good order, and [the association] stipulated to waive its right to file a motion for attorney fees and dismissed its own claim for breach of contract. [The association] stayed in the case for the purpose of being bound by any judgment issued by the court as to injunctive relief." Id.

${ }^{120} \mathrm{Id}$ at 524-25. 
tion to both new friends and old."121

The court ordered the Shpirts not to engage in further construction without approval from the homeowner's association. The Shpirts were further "enjoined and directed to clear and render the Shpirt Property in neat and clean condition, within 90 days, and to maintain the Shpirt Property in a neat and clean condition thereafter." ${ }^{\text {122 }}$ The court of appeals affirmed.

The Shpirts' lawyers said there were no negotiations after the court's decision about the possibility that the Shpirts might pay Ross to be free of the injunction's requirements. "Mr. Ross was just hell-bent on fighting every little thing," one of the Shpirts' lawyers said. But he didn't think there would have been any bargaining if the Shpirts had won the right to leave their house in the condition that bothered Ross. "There's just a lot of hostility between the neighbors," the lawyer said, and it foreclosed the possibility of bargaining either way. "Before the suit there were some discussions [of settlement without litigation], but they didn't go anywhere," he said. Ross's lawyer concurred: "the parties really don't like each other," he said; he thought that on account of the "animosity" between the parties, there would have been no bargaining over the nuisance aspects of the case no matter which way the court decided it. He noted that there had been some attempts at bargaining over other aspects of the case, but again agreed that they had not amounted to anything. One of Ross's complaints was that the Shpirts' improvements would obstruct a pleasing view from his house. At one point the Shpirts offered to pay for changes in Ross's house so that the view would be preserved out of a new window elsewhere. The Rosses declined; "they liked their house the way it was," their lawyer said. The bank ultimately foreclosed on the Shpirts' house.

Miller $v$ Horn. ${ }^{123}$ In 1957, Ann Horn and her husband, David, purchased some real estate in Clark County, Missouri. A year later, Ray Miller and his wife bought some property next door. Soon the Horns began taking in and caring for stray animals; they also established a pet cemetery on several acres behind their house. In 1973 the Horns bought an adjacent property and moved there, turning their previous house into a sanctuary for homeless animals and a kennel for cats, the Kozy Kat Motel. After Mr. Horn died in 1991, Mrs. Horn continued this occupation, to the consternation of the Millers.

The Millers complained about the odors and noise emanating from the Horns' operation for many years. They had asked the local prosecutor to investigate the possibility that the kennel and cemetery violated zoning ordinances, but the prosecutor's office would not pursue the claim, and the local zoning board eventually ruled that the Horns' use of their premises was lawful because it was established prior to the zoning of the area as residential in 1964. In 1993, the Millers brought a lawsuit to enjoin the keeping of dogs and cats on Mrs. Horn's premises. Some other families in the neighborhood (seven to ten of them, the plaintiffs' lawyer estimated) joined as plaintiffs, though the Millers were the driving force behind the suit. The trial court found a nuisance and granted the injunction, ordering Mrs. Horn to remove all dogs, cats, and manure piles from her property. The court of appeals considered this a "draconian" remedy, however, and remanded for entry of an injunction that would give Mrs. Horn a reasonable amount of time to get rid of the animals and would allow her to keep a reasonable number of them as personal pets. ${ }^{124}$ The trial court entered an elaborate revised injunction, this time allowing Mrs. Horn to keep a certain number of dogs and cats but regulating the amount of time they could be allowed outside, requiring her to take various steps with respect to waste the animals created, and requiring her to remove all visible markers in the pet cemetery and close off public access to it.

The lawyer for the plaintiffs said the Millers enforced the injunction, and that they did not discuss the possibility of selling to Mrs. Horn the right to continue operating the kennel and cemetery. Nor was there any possibility that Mrs. Horn might buy the Millers'

${ }^{121}$ Id.

${ }^{122}$ Id at 526.

${ }^{123} 1996$ Ohio App LEXIS 2678. This account is based on the opinion in the case, and on a telephone interview with the lawyer for the plaintiffs (Feb 11, 1998).

${ }^{124}$ Id at $* 17$. 
house; it was worth between $\$ 100,000$ and $\$ 200,000$, and the plaintiffs' attorney doubted that Mrs. Horn had more than $\$ 5,000$ to her name. He also said he was sure that if Mrs. Horn had won, there would have been no discussion of the possibility that the plaintiffs might have paid her to close the operation down. "This lady was so eccentric; animals were more important to her than humans. No amount of money would have been enough to get her to stop." And only "in jest" had the plaintiffs ever discussed the idea of buying Mrs. Horn's property. (Mrs. Horn's will apparently leaves her property to the local animal rights league.) The other major obstacle to a bargain was the bad blood that had developed between the parties over the years. "She thumbed her nose at the neighbors" and suggested that they should move if they didn't like the kennel, the lawyer said. "There were a lot of emotions involved, a lot of ill will." In the later years of the dispute, Mrs. Horn had a hearing aid, and her response when neighbors complained was "to turn it off and flip 'em the bird." 